\title{
TRANSFERENCIAS Y COHESIÓN POLÍTICA DE GOBIERNOS DISIDENTES EN MÉXICO
}

\section{TRANSFERENCE AND POLITICAL COHESION OF DISSIDENT GOVERNMENTS IN MEXICO}

\author{
Alfonso Mendoza-Velázquez, Miguel Cruz-Vásquez* \\ Universidad Popular Autónoma del Estado de Puebla. (alfonso.mendoza@upaep.mx), (miguel. \\ cruz@upaep.mx)
}

\begin{abstract}
RESUMEN
La hipótesis de integración establece que las transferencias pueden utilizarse como instrumentos de adhesión, más que como incentivos para reforzar la autonomía fiscal. En la presente investigación sometemos a prueba esta hipótesis examinando los montos diferenciales de transferencias asignados a municipios regidos por usos y costumbres y a municipios regidos por partidos políticos, utilizando información de los 570 municipios del Estado de Oaxaca. Determinamos el impacto dinámico de las participaciones y las aportaciones sobre el esfuerzo fiscal de los dos tipos de municipios mediante Vectores Autorregresivos (VAR) y distinguimos el dinamismo de las variables fiscales y los factores comunes en ambos tipos de municipios. Encontramos que los municipios de usos y costumbres han recibido mayores transferencias federales per cápita; que las participaciones ejercen un impacto positivo y persistente sobre la recaudación propia del municipio; que las aportaciones tienen un impacto negativo y persistente sobre la recaudación propia; que las aportaciones impactan negativamente a las participaciones, y que las participaciones impactan positivamente a las aportaciones.
\end{abstract}

Palabras clave: autonomía fiscal, federalismo fiscal, usos y costumbres.

\section{INTRODUCCIÓN}

$\mathrm{E}$ 1 estudio de la interrelación fiscal entre la federación y las fuerzas políticas locales puede ser abordado en general desde dos enfoques: desde el enfoque normativo, centrado en la racionalidad económica de las transferencias (Boadway y Hobson 1993), y desde el enfoque positivo, que explica la descentralización como resultado de la pugna político-democrática local (Johansson, 2003).

* Autor responsable * Author for correspondence.

Recibido: junio, 2016. Aprobado: octubre, 2017.

Publicado como ARTÍCULO en ASyD 16: 239-267. 2019.

\begin{abstract}
The integration hypothesis proposes that transferences can be used as instruments of adhesion, rather than as incentives to reinforce fiscal autonomy. In this study, we test this hypothesis by examining the differential amounts of transferences allotted to municipalities ruled by uses and customs and to municipalities ruled by political parties, using information from the 570 municipalities of the state of Oaxaca. We established the dynamic impact of participations and contributions on the fiscal effort of the two types of municipalities through Autoregressive Vectors (ARV) and we distinguish the dynamism of fiscal variables and the common factors in both types of municipalities. We find that the municipalities with uses and customs have received higher federal transferences per capita; that participations exert a positive and persistent impact on the municipality's own tax collection; that contributions have a negative and persistent impact of the municipality's own tax collection; that contributions impact negatively the participations; and that participations impact positively the contributions.
\end{abstract}

Key words: fiscal autonomy, fiscal federalism, uses and customs.

\section{INTRODUCTION}

$\mathrm{T}$ The study of the fiscal interrelation between the federation and the local political forces can be generally addressed from two approaches: from the normative approach, centered on the economic rationality of the transferences (Boadway and Hobson 1993), and from the positive approach, which explains decentralization as a result of the local political-democratic struggle (Johansson, 2003).

In the normative approach, decentralization is considered to be a promotion mechanism for fiscal competition between local governments. As such, transferences are incentives that may correct, but may also accentuate the defects of this struggle. The 
En el enfoque normativo, la descentralización es vista como un mecanismo de promoción de la competencia fiscal entre los gobiernos locales. Como tal, las transferencias son incentivos que pueden corregir, pero también acentuar las fallas de esa pugna. El enfoque positivo en cambio trata a la descentralización como resultado de la interacción entre los agentes interesados (stakeholders) en el gobierno local (Sato, 2007). Los patrones de comportamiento, el estilo y monto de las transferencias, así como el esfuerzo y la autonomía fiscal de los gobiernos locales son resultado de la estructura institucional creada por los agentes.

El enfoque de economía política positiva es muy atractivo, pues permite explicar algunas características relevantes de las relaciones interregionales y de las transferencias, tales como la influencia política de grupos sociales específicos (rent seeking), así como su capacidad de atracción de recursos federales (Inman y Rubinfeld, 1996). También integra el estudio de problemas de agencia, donde grupos organizados con mayor influencia política, pueden acceder a mayores fondos (Dixit et al., 1997).

Algunos autores también han examinado la posibilidad de que la pugna política de las regiones den lugar a un tratamiento federal asimétrico. Con el fin de asegurar la estabilidad y la cooperación de las regiones, las transferencias federales pueden ser empleadas por el gobierno central como mecanismos de adhesión, más que como incentivos al esfuerzo fiscal de los gobiernos locales (Inman y Rubinfeld, 1997). Bolton y Roland (1997) han reportado por ejemplo que municipios en descontento social reciben más transferencias; mientras que Leite-Monteiro y Sato (2003) encuentran que las transferencias son empleadas como gastos de inversión para mantener la unidad de las regiones.

Los estudios sobre federalismo asimétrico y el empleo de las trasferencias como instrumentos de cohesión regional y social son escasos para países en desarrollo. No existen suficientes estudios sobre el impacto del tratamiento fiscal diferenciado sobre el esfuerzo recaudatorio de las regiones en el mundo o en Latino América. En este artículo buscamos cubrir estos espacios en la literatura explorando, primero, la evidencia sobre federalismo asimétrico: si las transferencias federales a municipios disidentes muestran niveles y dinámica distintos al de municipios dentro de la norma política. Segundo, examinamos la posibilidad de que las transferencias federales incentiven positive approach, instead, deals with decentralization as a result of the interaction between the agents interested (stakeholders) in the local government (Sato, 2007). The patterns of behavior, the style and amount of transferences, as well as the fiscal effort and autonomy of local governments are the result of the institutional structure created by the agents.

The approach of positive political economy is very attractive, since it allows explaining some relevant characteristics of inter-regional relations and of transferences, such as the political influence of specific social groups (rent seeking), as well as their capacity to attract federal resources (Inman and Rubinfeld, 1996). It also integrates the study of problems of agency, where organized groups with greater political influence can gain access to more funds (Dixit et al., 1997).

Some authors have also examined the possibility that political struggles of the regions give place to an asymmetrical federal treatment. With the aim of ensuring the stability and cooperation of the regions, federal transferences can be used by the central government as adhesion mechanisms, rather than as incentives to the fiscal effort of local governments (Inman and Rubinfeld, 1997). Bolton and Roland (1997) have reported, for example, that municipalities with social discontentment receive more transferences, while Leite-Monteiro and Sato (2003) find that transferences are used as investment spending to maintain the unity of the regions.

Studies about asymmetrical federalism and the use of transferences as instruments of regional and social cohesion are scarce for developing countries. There are not enough studies about the impact of differentiated fiscal treatment on the tax collecting effort of the regions in the world or in Latin America. In this article we seek to cover these spaces in the literature by exploring, first, the evidence on asymmetric federalism: whether federal transferences to dissident municipalities show levels and dynamics different from the municipalities within the political norm. Second, we examine the possibility of federal transferences stimulating the tax collecting effort of local governments, as well as the intensity and the substitution among transferences by type of political regime.

In order to do this, we use information about the municipalities of the state of Oaxaca in Mexico, one of the few federal entities in Mexico where we 
el esfuerzo recaudatorio de los gobiernos locales, así como la intensidad y la sustitución entre las transferencias por tipo de régimen político.

Para tal efecto empleamos información sobre los municipios del Estado de Oaxaca en México, una de las pocas entidades federativas en México en las que podemos realizar una distinción clara entre municipios insertos en la normalidad democrática del país y aquellos en sistemas políticos alternativos como los denominados usos y costumbres $(\mathrm{UyC})$, que identificamos en este estudio como municipios en descontento con la normalidad partidaria. Un monto de transferencias mayor y más persistente hacia municipios en descontento, además de un esfuerzo recaudatorio bajo proveen evidencia de un federalismo asimétrico, orientado a mantener la estabilidad y la cohesión político-social, más que incentivar la autonomía fiscal de los gobiernos locales.

Dada la evidencia aún no concluyente respecto al impacto de las trasferencias federales sobre el esfuerzo fiscal de los municipios en México, en este estudio también contribuimos a la literatura examinando la causalidad dinámica y la persistencia de las transferencias federales sobre la recaudación municipal utilizando un modelo de Vectores Autorregresivos (VAR) para datos panel, mediante el Método Generalizado de Momentos (GMM). De acuerdo con nuestra revisión de literatura, este es el primer estudio que mide la influencia dinámica de estos factores para gobiernos locales conformados bajo el régimen de usos y costumbres.

\section{POLÍTICA ECONÓMICA DE LAS TRANSFERENCIAS: REVISIÓN BREVE DE LITERATURA}

En este artículo seguimos el enfoque positivo de los modelos de política económica que sugiere que el diseño de las transferencias y la autonomía de los municipios se determinan por la pugna política entre los agentes interesados (stakeholders) de los gobiernos locales (Sato, 2007). Identificamos en este estudio tres teorías que explican las transferencias como resultado de la pugna política entre los agentes: maquinaria política (machine politics), votantes indecisos (swing voters) e integración política.

El primer enfoque, la teoría de la maquinaria política (machine politics), sugiere que las transferencias se dirigen en mayor medida a favor de grupos de soporte político a costa de grupos disidentes o adversarios can make a clear distinction between municipalities inserted in the democratic normalcy of the country and those in alternative political systems like the so called uses and customs (U\&C), which we identify in this study as municipalities in discontentment with partisan normalcy. A higher and more persistent amount of transferences towards municipalities in discontentment, in addition to a low tax collection effort provide evidence of asymmetric federalism, directed at maintaining the stability and politicalsocial cohesion, rather than stimulating the fiscal autonomy of local governments.

Given the still inconclusive evidence regarding the impact of federal transferences on the fiscal effort of municipalities in Mexico, in this study we also contribute to the literature by examining the dynamic causality and the persistence of federal transferences on municipal tax collection using a model of Autoregressive Vectors (ARV) for the panel data, through the Generalized Moments Method (GMM). According to our literature review, this is the first study that measures the dynamic influence of these factors on local governments shaped under the regime of uses and customs.

\section{ECONOMIC POLICY OF THE TRANSFERENCES: BRIEF LITERATURE REVIEW}

In this article we follow the positive approach of the economic policy models that suggest that the design of transferences and the autonomy of municipalities are determined by the political struggle between the agents interested (stakeholders) of local governments (Sato, 2007). We identify in this study three theories that explain the transferences as a result of the political struggle between the agents: machine politics, swing voters, and political integration.

The first approach, the theory of machine politics suggests that the transferences are directed mostly in favor of groups of political support at the expense of dissident or adversary groups (Dixit and Londregan, 1996). The greater the political capital and the hard vote of this group are in favor of the federation, the higher the amount of the transferences will be (Porto and Sanguinetti, 2001). The second approach (swing voters) points out that the competition over indecisive votes can also define the relationship between the federation and local governments. Some 
(Dixit and Londregan, 1996). Entre mayor sea el capital político y el voto duro de estos grupos a favor de la federación, mayor será el monto de las transferencias (Porto y Sanguinetti, 2001). El segundo enfoque (swing voters) señala que la competencia por votos indecisos también puede determinar la relación entre la federación y los gobiernos locales. Algunos autores han encontrado que grupos con menos adhesión política, con más votos indecisos, al igual que aquellos con menores ingresos, tienden a recibir más transferencias que aquellos insertos en la competencia partidista (Boadway, 2002 Dixit \& Londregan, 1998). El tercer enfoque examina la relación entre la federación y los gobiernos locales en un contexto de integración política. En esta corriente se considera que un gobierno central puede usar las transferencias para mantener unida a una región frente a movimientos separatistas. De esta manera, mayores transferencias serían destinadas a municipios disidentes para mantener la estabilidad y cohesión política (Sato, 2007).

En este tercer enfoque las transferencias pueden ser empleadas como mecanismos de integración política, i.e., para asegurar la cooperación, más que utilizarse como incentivos para los gobiernos locales (Inman y Rubinfeld, 1997). Sato (2007) destaca que puede generarse un tipo de federalismo asimétrico donde algunos municipios con mayor poder político y deseos separatistas reciben montos de transferencias mayores. Este patrón puede ser más evidente en regiones cultural, religiosa y lingüísticamente heterogéneas.

En este sentido, las transferencias mantienen la unidad nacional asegurando que el bienestar de estos municipios sea mayor dentro del pacto federal que fuera de este (Sato, 2007). La posibilidad separatista de las regiones sesga la política fiscal de las transferencias a favor de municipios en descontento (Bolton y Roland 1997). Leite-Monteiro y Sato (2003) han encontrado que en un entorno globalizado, los regímenes fiscales emanados de la negociación interregional, que a su vez emplean las transferencias como pagos adicionales para mantener la unidad de la nación, son preferibles a regímenes centralizados.

Becker (1983) había también contemplado la posibilidad de que las transferencias a regiones pequeñas sean relativamente más altas, ya que en conjunto algunos grupos pueden ejercer mayor presión y en suma mostrar una mayor capacidad de cabildeo (lobbying), no solo con las ramas del legislativo, sino authors have found that groups with less political adhesion, with more swing votes, as well as those with lower income tend to receive more transferences than those inserted in the partisan competition (Boadway, 2002 Dixit \& Londregan, 1998). The third approach examines the relationship between the federation and local governments in a context of political integration. In this current it is considered that a central government can use the transferences to keep a region united in face of separatist movements. Thus, higher transferences would be destined to dissident municipalities to maintain stability and political cohesion (Sato, 2007).

In this third approach, the transferences can be used as mechanisms of political integration, that is, to ensure cooperation, rather than being used as incentives for local governments (Inman and Rubinfeld, 1997). Sato (2007) highlights that a type of asymmetric federalism can be generated, where some municipalities with higher political power and separatist desires receive higher transference amounts. This pattern can be more evident in regions that are culturally, religiously and linguistically heterogeneous.

In this sense, the transferences maintain national unity by ensuring that the welfare of these municipalities is higher within the federal pact than outside of it (Sato, 2007). The separatist possibility of the regions distorts the fiscal policy of the transferences in favor of the municipalities in discontentment (Bolton and Roland 1997). LeiteMonteiro and Sato (2003) have found that in a globalized environment, fiscal regimes emanating from inter-regional negotiation, which in turn use transferences as additional payments to maintain the unity of the nation, are preferable to centralized regimes.

Becker (1983) had also contemplated the possibility that the transferences to small regions would be relatively higher, since as a whole some groups can exert greater pressure and in sum show a higher lobbying capacity, not only with the legislative branches, but also with the executive power itself. In addition, framed within a problem of agency, Dixit et al. (1997) note that organized groups with higher political influence have more access to federal funds than unorganized groups. Brock and Owings (2003) and Grossman (1994) find that the amount of transferences per capita is positively correlated to 
con el propio ejecutivo. Adicionalmente, enmarcado en un problema de agencia, Dixit et al. (1997) nota que grupos organizados, con mayor influencia políti$\mathrm{ca}$, tienen mayor acceso a fondos federales que aquellos grupos no organizados. Brock y Owings (2003) y Grossman (1994) encuentran que la cantidad de transferencias per cápita está correlacionada positivamente con la cercanía, no solo geográfica, sino también política de los grupos.

La teoría de las organizaciones también señala la posibilidad de que surja el denominado problema de interrupción (hold-up problem), en el que municipios pueden mostrar una baja recaudación si perciben que un mayor esfuerzo fiscal se asocia a menores transferencias futuras. No solo se generan efectos negativos sobre los incentivos de recaudación futura, sino también desconfianza entre los gobiernos locales y la autoridad central (Zhuravskaya, 2000).

Además, los gobiernos locales podrían percibir a las transferencias como instrumentos de control, por lo que pueden representar un costo en términos de la pérdida de autonomía (Alesina y Spolaore, 1997; Bolton y Roland, 1997). Aquellos municipios que buscan mantener o consolidar su autonomía, incrementando su fortaleza política como grupo, podrían también estar renunciando a la adopción de los criterios y la lógica de reparto fiscal federal.

Este trabajo tiene varios objetivos. En principio, explora la evidencia a favor de federalismo asimétrico (Sato, 2007); si los municipios elegidos democráticamente son más eficientes en la recaudación propia (Wittman, 1995); si municipios en competencia partidaria enfrentan menores costos para la recaudación relativa, (Alesina y Spolaore 1997; Bolton y Roland, 1997) y si mayor recaudación propia está relacionada con caídas en los montos de transferencias [dentro de la lógica de rescate financiero ex post para evitar inestabilidad política,(Zhuravskaya, 2000)].

\section{Esfuerzo fiscal y transferencias en México}

Uno de los objetivos del pacto federalista actual en México es incentivar el esfuerzo fiscal de los municipios, por lo que se esperaría que mayores ingresos estuvieran asociados con mayores montos de transferencias no condicionadas (participaciones), Cárdenas y Sharma (2011). Sin embargo, la evidencia aún no ha alcanzado consenso. Por ejemplo, analizando el impacto de la ayuda federal sobre el gasto de los the proximity, not just geographic but also political, of the groups.

Organizational theory also points to the possibility of the emergence of the hold-up problem, in which municipalities can show low tax collection if they perceive that a greater fiscal effort is associated to lower future transferences. Not only are negative effects generated on the incentives of future collection, but also mistrust between local governments and the central authority (Zhuravskaya, 2000).

In addition, local governments could receive the transferences as instruments of control, which is why they can represent a cost in terms of the loss of autonomy (Alesina and Spolaore, 1997; Bolton and Roland, 1997). Those municipalities that seek to maintain or consolidate their autonomy, increasing their political strength as a group, could also be renouncing to the adoption of the criteria and the logic of federal fiscal distribution.

This study has several objectives. In principle, it explores the evidence in favor of asymmetric federalism (Sato, 2007); whether the municipalities chosen democratically are more efficient in their own tax collection (Wittman, 1995); whether the municipalities in partisan competition face lower costs for relative collection (Alesina and Spolaore 1997; Bolton and Roland, 1997); and whether higher collection of their own is related with drops in the amounts of transferences [within the logic of ex post financial rescue to avoid political instability (Zhuravskaya, 2000)].

\section{Fiscal effort and transferences in Mexico}

One of the objectives of the current federalist pact in Mexico is to stimulate the fiscal effort of municipalities, which is why it would be expected that higher income would be associated with higher amounts of unconditioned transferences (participations), Cárdenas and Sharma (2011). However, the evidence still has not reached consensus. For example, analyzing the impact of federal help on spending by local governments, Benton (1992) found that their own income dropped with the federal backing, regardless of the relative amount. In turn, Bell and Bowman (1987) and Stine (1994) did not find a significant effect of the state help on the autonomy of local governments. Peña and Wence (2011) mention the importance of the 
gobiernos locales, Benton (1992) encontró que los ingresos propios caían con la ayuda federal, independientemente del monto relativo. Bell y Bowman (1987) y Stine (1994) no encontraron por su parte un efecto significativo de la ayuda estatal sobre la autonomía de los gobiernos locales. Peña y Wence (2011) mencionan la importancia del diseño de las transferencias para impulsar la recaudación propia en los municipios.

$\mathrm{Al}$ analizar la existencia del efecto papel matamoscas en los estados de México para el periodo 1993-2002, Guadarrama (2006) reportó que el incremento de las transferencias federales redujo el esfuerzo fiscal de las entidades federativas. Moreno (2003) reporta por su parte un incremento del esfuerzo recaudatorio a mayores transferencias no condicionadas (participaciones), pero menor recaudación como respuesta a mayores transferencias condicionadas (aportaciones), resultado que es compartido por (Unda y Moreno, 2015). Por su lado, Sobel y Crowley (2014) encuentran que las transferencias federales hacia los estados incrementan los ingresos tributarios (y los propios impuestos).

En cambio, Sour $(2004,2008)$ encuentra impactos negativos de las transferencias, sobre la autonomía fiscal. Sour (2008) emplea datos panel de 155 municipios urbanos para el período 1993-2000, mientras que Sour (2004) incluye datos panel de 2,412 gobiernos municipales de 1993 a 2004. En ambos estudios, la autora encuentra que las transferencias ejercen un estímulo negativo sobre la recaudación propia, pues los gobiernos locales prefieren recibir las transferencias que enfrentar los costos políticos y administrativos de la recaudación tributaria propia.

Otros estudios se han preocupado por medir el impacto de la autonomía fiscal sobre las transferencias; también con conclusiones mixtas. Por ejemplo, utilizando datos de corte transversal del año 2004 para las 31 entidades federativas del país, Cabrera y Lozano (2011) reportan un impacto significativo del grado de autonomía (medido por la participación de ingresos propios de los ingresos totales) sobre las Participaciones Federales (Ramo 28) y el grado de autonomía financiera (medido como el porcentaje de ingresos propios entre los ingresos totales); también encuentran un impacto negativo estadísticamente significativo del grado de autonomía financiera sobre las Aportaciones Federales (Ramo 33).

Otros estudios empíricos, como el de Ibarra, Sandoval y Sotres (1999), encuentran que tanto design of transferences to foster tax collection in the municipalities.

When analyzing the existence of the fly swatter paper effect in the states of Mexico for the period of 1993-2002, Guadarrama (2006) reported that the increase of federal transferences reduced the fiscal effort of the federal entities. Moreno (2003) reports in turn an increase of the tax collecting effort to higher unconditioned transferences (participations), but lower collection as response to higher conditioned transferences (contributions), result that is shared by Unda and Moreno (2015). In their turn, Sobel and Crowley (2014) find that the federal transferences toward the states increase the tax collecting income (and their own taxes).

Instead, Sour $(2004,2008)$ finds negative impacts of the transferences on fiscal autonomy. Sour (2008) uses panel data from 155 urban municipalities for the period of 1993 to 2004. In both studies, the author finds that the transferences exert a negative stimulus on the municipality's tax collection, since the local governments prefer to receive the transferences than to face the political and administrative costs that result from their own tax collection.

Other studies have focused on measuring the impact of fiscal autonomy on the transferences, also with mixed conclusions. For example, using crosssectional data from the year 2004 for the 31 federal entities of the country, Cabrera and Lozano (2011) report a significant impact of the degree of autonomy (measured by the participation of own income from total income) on the Federal Participations (Branch 28 ) and the degree of financial autonomy (measured as the percentage of own income divided by the total income); they also find a negative impact that is statistically significant of the degree of financial autonomy on the Federal Contributions (Branch 33).

Other empirical studies, such as that by Ibarra, Sandoval and Sotres (1999), find that both the Fiscal Coordination System of 1980 (Sistema de Coordinacion Fiscal, SNCF) and the Constitutional Reform of Article 115 in 1983 reinforced the dependency of municipal public finance agencies on participations. These authors found evidence that the percentage that represented the participations in the average of municipal incomes was significantly higher in the periods of 1980-89 and 1990-95, compared to the period of 1975-79 (prior to the 
el Sistema de Coordinación Fiscal de 1980 (SNCF) como la Reforma del Artículo 115 Constitucional de 1983 reforzaron la dependencia de las haciendas públicas municipales a las participaciones. Estos autores hallaron evidencia de que el porcentaje que representaban las participaciones en el promedio de ingresos municipales era significativamente mayor en los períodos 1980-89 y 1990-95, en comparación con el período 1975-79 (anterior a la entrada en vigor del SNCF y la Reforma Constitucional). Asimismo, encontraron que tanto el SNCF de 1980 como la Reforma del Artículo 115 Constitucional de 1983 han tenido un impacto negativo sobre la Autonomía Fiscal de los municipios. La dependencia elevada de las haciendas públicas municipales respecto de las transferencias federales también ha sido documentada en el estudio de Isusquiza (2014) para el caso de México y en el de Bello y Espitia (2011) para el caso de Colombia.

\section{Autonomía fiscal y conformación política en México}

La relación entre competencia política y esfuerzo fiscal en México ha sido estudiada por Ibarra y González (2009), quienes analizan los efectos del entorno político sobre la autonomía financiera ${ }^{1}$. Entre otros resultados los autores encuentran que la filiación política del presidente municipal impacta la autonomía financiera dependiendo del partido político en tur$\mathrm{no}^{2}$. También encuentran que la autonomía financiera está condicionada positivamente por la confluencia política entre presidente municipal y gobernador; mientras que la confluencia política del presidente municipal y el congreso no parece relevante.

Ruiz Porras y García-Vázquez (2013) estudian por su parte la relación entre la dinámica de las transferencias per cápita y el origen partidario de los municipios del Estado de Jalisco para el período 20052011. Los autores reportan que entre 2005 y 2009 las transferencias hacia los municipios del Partido Revolucionario Institucional (PRI) (partido gobernante en la mayoría de municipios), son más altas que aquellas de los municipios del Partido Acción Nacional (PAN). En 2010 esta situación se revierte en favor del PAN y municipios donde gobiernan otros partidos reciben menos transferencias. Asimismo, Ruiz Porras y García-Vázquez (2014) analizan los criterios económicos y políticos en las transferencias intergubernamentales y encuentran que durante el período enforcement of the SNCF and the Constitutional Reform). Likewise, they found that both the SNCF of 1980 and the Constitutional Reform of Article 115 in 1983 have had a negative impact on the Fiscal Autonomy of the municipalities. The increased dependency of municipal public finance agencies regarding the federal transferences has also been documented in the study by Isusquiza (2014) for the case of Mexico and by Bello and Espitia (2011) for the case of Colombia.

\section{Fiscal autonomy and political configuration in Mexico}

The relationship between political competition and fiscal effort in Mexico has been studied by Ibarra and González (2009), who analyze the effects of the political environment on financial autonomy ${ }^{1}$. Among other results the authors find that the political affiliation of the municipal president impacts the financial autonomy depending on the political party in power ${ }^{2}$. They also find that financial autonomy is conditioned positively by the political confluence between the municipal president and the governor, while the political confluence of the municipal president and the congress does not seem relevant.

Ruiz Porras and García-Vázquez (2013) study for their part the relationship between the dynamics of the per capita transferences and the partisan origin of the municipalities in the state of Jalisco for the period of 2005-2011. The authors report that between 2005 and 2009, the transferences toward municipalities of the Partido Revolucionario Institucional (PRI) (ruling party in most of the municipalities), are higher than those in the municipalities of Partido Acción Nacional (PAN). In 2010 this situation reverts in favor of PAN and the municipalities where other parties rule receive less transferences. Likewise, Ruiz Porras and GarcíaVázquez (2014) analyze the economic and political criteria in inter-government transferences and find that during the period of 2005-2011 they increased for the municipalities ruled by PAN, PRI and other parties in 41.1, 26.2 and 34.9\%, with the PAN municipalities being the ones that obtained higher increases in this period, when coincidentally this party controlled the Presidency of the Republic and the Governorship of the State, suggesting that there really was a political criterion in the allotment of transferences toward the municipalities. 
2005-2011 éstas aumentaron para los municipios gobernados por el PAN, el PRI y otros partidos en 41.1, 26.2 y $34.9 \%$, siendo los municipios del PAN los que obtuvieron los mayores incrementos en dicho período, en el que coincidentemente ese partido controlaba la Presidencia de la República y la Gubernatura del Estado, por lo que sugieren que efectivamente hubo un criterio político en la asignación de las transferencias hacia los municipios.

Díaz Cayeros (2004) mostró que el porcentaje de votos recibidos por el PRI en las 31 entidades federativas en 1998 se correlacionó de manera positiva y significativa con la distribución de las Aportaciones, pero no con las Participaciones.

Ibarra y Sotres (2009) explican la recaudación del impuesto predial como función de variables políticas que representa el período gubernamental el partido político del presidente municipal en turno. Los autores encuentran una relación indefinida, no significativa entre la recaudación del predial y el período de gobierno municipal, y una relación negativa pero no significativa entre recaudación de predial y la filiación política del presidente municipal. No obstante, Ibarra (2011) encuentra una relación no significativa entre la recaudación del predial y el período de gobierno cuando el gobernador y el Presidente de la República son del mismo partido, pero cuando el gobernador y el congreso son del mismo partido si hay una menor independencia financiera cuando se trata del PRI y mayor independencia financiera cuando se trata de otros partidos.

Sin embargo, en nuestra revisión de literatura para México no encontramos referencias que asocien el esfuerzo fiscal de los municipios con el origen político de los gobiernos locales, en particular distinguiendo si son emanados de la lucha partidaria o de otros procesos como los usos y costumbres en el Estado de Oaxaca.

\section{Oaxaca: el caso de estudio}

Con el fin de examinar si el estilo de pugna política y democrática de los gobiernos locales moldea los niveles y la dinámica de las transferencias de la federación hacia los municipios, en este artículo utilizamos una muestra con ayuntamientos emanados de procesos políticos partidarios y por usos y costumbres. Esta muestra de municipios permite examinar las hipótesis planteadas en las
Díaz Cayeros (2004) showed that the percentage of votes received by the PRI in the 31 federal entities in 1998 was correlated positively and significantly with the distribution of the Contributions, but not with the Participations.

Ibarra and Sotres (2009) explain property tax collection as a function of political variables representing the government period of the political party of the municipal president in turn. The authors find an indefinite, non-significant relationship between property tax collection and the period of municipal government, and a negative but non-significant relationship between property tax collection and the political affiliation of the municipal president. However, Ibarra (2011) finds a non-significant relationship between property tax collection and the government period when the governor and the President of the Republic belong to the same party, although when the governor and the congress belong to the same party there is lower financial independence when it is PRI and higher financial independence when it is other parties.

Nevertheless, in our literature review for Mexico we do not find references that associate the fiscal effort of the municipalities with the political origin of the local governments, in particular differentiating if they emanate from the partisan struggle or from other processes such as uses and customs in the state of Oaxaca.

\section{Oaxaca: the study case}

With the aim of examining whether the style of political and democratic struggle of the local governments shapes the levels and the dynamics of transferences from the federation toward the municipalities, in this article we use a sample with municipalities emanated from partisan political processes and from uses and customs. This sample of municipalities allows examining the hypothesis suggested in the prior section: machine politics, swing voters and political integration.

Oaxaca is one of the three federal entities where local governments may be chosen using the scheme of uses and customs, an alternative constitutional political origin to the system based on political parties $^{3}$. This differentiated political-cultural origin also allows assuming that the style of government can respond to criteria of their own, not necessarily aligned to the federalist pact. 
sección anterior: maquinaría política (machine politics), votantes indecisos (swing voters) e integración política.

Oaxaca es una de las tres entidades federativas donde pueden elegirse ayuntamientos empleando el esquema de usos y costumbres, un origen político constitucional alterno al sistema basado en partidos políticos ${ }^{3}$. Este origen político-cultural diferenciado también hace suponer que el estilo de gobierno puede obedecer a criterios propios, no necesariamente alineados al pacto federalista.

Existen además, razones de índole socio cultural que hacen suponer que la relación fiscal en municipios regidos por usos y costumbres es distinta a la de los municipios elegidos por partidos. Entre otros autores, Labastida et al. (2009) señala que el sistema de usos y costumbres constituye una fuente primaria de cohesión social, mucho más fuerte que la emanada de otras instituciones del estado. En estos municipios, las prioridades del gasto público pueden ser distintas en términos de educación por ejemplo, y la contribución fiscal puede dotarse a través de trabajo a favor del beneficio colectivo (Tequio). En estos municipios con identidad y cultura indígenas muy propias, también se reporta en general una percepción negativa de la población hacia los partidos políticos, que compiten en la práctica con estructuras jerárquico-religiosas. El levantamiento de la población indígena en el Estado de Chiapas en el año de 1994 encendió focos amarillos, no solo en esa entidad federativa, sino en toda la región sur del país, incluyendo Oaxaca. Algunos autores identifican el levantamiento Zapatista como el antecedente directo que motivó la elevación a rango constitucional del régimen de Usos y Costumbres. En efecto, tanto la Ley de Elecciones por Usos y Costumbres de 1995, los Acuerdos de San Andrés Larrainzar de 1996, las reformas a las Leyes secundarias en la Constitución y la Ley en Materia de Derechos y Cultura Indígena de 2001, dotaron todas de autonomía política y legalidad a estos municipios. Algunos autores señalan que, además de la fuerte intervención de la policía y el ejército en búsqueda de células del Ejército Zapatista de Liberación Nacional (EZLN), la legalización de usos y costumbres en Oaxaca detuvo el surgimiento de movimientos armados en 1995 (Owalabi, 2004). Otros autores anotan que en Oaxaca, sin embargo, los municipios de usos y costumbres han mantenido su posición de resistencia para preservar sus costumbres, lenguaje y tierras,
There are also reasons of sociocultural nature that might suggest that the fiscal relationship in municipalities ruled by uses and customs is different from the municipalities chosen by parties. Among other authors, Labastida et al. (2009) points out that the system of uses and customs constitutes a primary source of social cohesion, much stronger than the one emanated from other state institutions. In these municipalities, the priorities of public spending can be different in terms of education, for example, and the fiscal contribution can be given through work in favor of the collective benefit (Tequio). In these municipalities with indigenous identity and culture of their own, a general negative perception by the population toward political parties is also reported, which compete in practice with hierarchical-religious structures.

The uprising of the indigenous population in the state of Chiapas in the year 1994 lit spotlights, not just in this federal entity, but in the whole southern region of the country including Oaxaca. Some authors identify the Zapatista uprising as the direct antecedent that motivated the elevation to constitutional range of the Uses and Customs regime. In fact, both the Law of Elections by Uses and Customs of 1995 , the San Andrés Larrainzar Agreements of 1996, the reforms to the secondary Laws in the Constitution and the Law in Matters of Indigenous Rights and Culture of 2001, all gave political autonomy and legality to these municipalities.

Some authors point out that, in addition to the strong intervention of the police and the army in the search of cells of the Zapatista Army of National Liberation (Ejército Zapatista de Liberación Nacional, EZLN), the legalization of uses and customs in Oaxaca stopped the emergence of armed movements in 1995 (Owalabi, 2004). Other authors note that in Oaxaca, however, the municipalities of uses and customs have maintained their position of resistance to preserve their customs, language and lands, even long before the appearance of Zapatistas in Chiapas (Mendoza, 2009). This process of integration and political recognition as a group seems to have buffered the political and social discontentment in later years, but it could also have generated a federalist asymmetry between the municipalities chosen by uses and customs and those chosen in partisan struggles by giving them higher amounts of federal transferences ${ }^{4}$. And, however, little or nothing 
incluso mucho antes de la aparición de los Zapatistas en Chiapas (Mendoza, 2009).

Este proceso de integración y reconocimiento político como grupo parece haber amortiguado el descontento político y social en ańos posteriores, pero también pudo haber generado una asimetría federalista entre los municipios elegidos por usos y costumbres y aquellos elegidos en pugnas partidarias al dotarlos de montos mayores de transferencias federales ${ }^{4}$. $\mathrm{Y}$, sin embargo, poco o nada se ha estudiado acerca de este tema o del impacto de este choque políticosocial sobre la autonomía fiscal de los municipios. Se desconoce también el impacto sobre las relaciones municipales con la federación y del efecto sobre los incentivos fiscales de estos municipios respecto de los municipios elegidos por partidos políticos. En secciones siguientes retomamos en particular el caso de Oaxaca para probar las hipótesis de federalismo fiscal asimétrico.

\section{VAR CON DATOS PANEL}

La metodología de datos panel es el enfoque de estimación apropiado para muestras donde se tiene un conjunto de unidades económicas (municipios) que evolucionan en el tiempo. Sin embargo, la metodología de datos panel estándar no explota totalmente la interrelación dinámica y la respuesta de las variables ante choques. Por esta razón, en este estudio extendemos la metodología de Vectores Autorregresivos (VAR) a datos tipo panel, lo que permite analizar las interrelaciones de las variables y sus efectos en las dimensiones temporales y transversales. Al mismo tiempo, la metodología permite capturar la heterogeneidad no observada de los municipios en el Estado de Oaxaca, así como medir características temporales individuales y conjuntas de las variables bajo estudio. El VAR con datos tipo panel a emplear para el estudio de la autonomía municipal y el impacto de las transferencias se especifica de la siguiente manera:

$$
\begin{aligned}
& z_{i, t}=\Gamma_{0}+\sum_{j=1}^{k} \Gamma_{j} z_{i, t-j}+f_{i}+d_{t}+e_{i} \\
& (i=1, \ldots, N ; t=1, \ldots, T)
\end{aligned}
$$

donde el vector de variables endógenas $z_{i, t-j}$ incluye tres variables: la recaudación propia, el monto de las aportaciones y las participaciones federales para cada municipio $i$ y para cada rezago $t-j$ con has been studied about this theme or the impact of this political-social shock on the fiscal autonomy of the municipalities. The impact on the municipal relationships with the federation and the effect on the fiscal incentives of these municipalities compared to the municipalities chosen by political parties are also unknown. In the next sections we take up again, in particular, the case of Oaxaca to test the hypothesis of asymmetrical fiscal federalism.

\section{ARV WITH PANEL DATA}

The methodology of the panel data is the appropriate estimation approach for samples where there is a set of economic units (municipalities) that evolve in time. However, the methodology of standard panel data does not exploit completely the dynamic interrelation and the response of variables in face of shocks. For this reason, in this study we extend the methodology of Autoregressive Vectors (ARV) to panel type data, which allows analyzing the interrelations of the variables and their effects on the temporal and transversal dimensions. At the same time, the methodology allows capturing the heterogeneity that is not observed in the municipalities of the state of Oaxaca, as well as measuring individual and joint temporal characteristics of the variables under study. The ARV with panel type data to be used for the study of municipal autonomy and the impact of the transferences are specified in the following manner:

$$
\begin{aligned}
& z_{i, t}=\Gamma_{0}+\sum_{j=1}^{k} \Gamma_{j} z_{i, t-j}+f_{i}+d_{t}+e_{i} \\
& (i=1, \ldots, N ; t=1, \ldots, T)
\end{aligned}
$$

where the vector of endogenous variables $z_{i, t-j}$ includes three variables: municipal tax collection, amount of contributions, and federal participations for each municipality $i$ and for each lag $t-j$ with $j=[0, \ldots, k]$. The marginal impacts $g_{i j}$ are contained in $G_{j}$ for each $\operatorname{lag} j>=1$. With the aim of measuring the individual heterogeneity of the municipalities, $f_{i}$ is included, and $d_{t}$ is included to capture the temporal heterogeneity.

In this specification, the fixed effects are correlated with the explicative variables and particularly with their lags $z_{i, t j^{j}}$ The violation to the assumption of independence is usually corrected differentiated; however, in the case of ARV with panel data, this 
$j=[0, \ldots, k]$. Los impactos marginales $g_{i j}$ están contenidos en $G_{j}$ para cada rezago $j>=1$. Con el fin de medir la heterogeneidad individual de los municipios se incluye $f_{i}$, y para capturar la heterogeneidad temporal se incluye $d_{t}$.

En esta especificación los efectos fijos están correlacionados con las variables explicativas y en particular con sus rezagos $z_{i, t, j}$ La violación al supuesto de independencia usualmente se corrige diferenciando; sin embargo, en el caso del VAR con datos panel, tal diferenciación induciría sesgo en los parámetros estimados. Para evitar este problema y asegurar la ortogonalidad entre los efectos fijos y los rezagos de las variables, en nuestro ejercicio econométrico empleamos la diferenciación adelantada respecto a la media, conocida como el procedimiento de Helmert, de Arellano y Bover (1995)5.

La extensión de modelo VAR con datos panel que proponemos aquí considera además la posibilidad de que los municipios del Estado de Oaxaca sean afectados de manera común en determinados puntos del tiempo. Esta posibilidad se mide por $d_{t}$ que aproxima el impacto de efectos económicos macro regionales compartidos por todos los municipios que no están incluidos en $z_{i, t}$ o ninguno de sus rezagos. En este caso, el efecto fijo se elimina aplicando desviaciones de cada variable respecto a la media para cada municipio y año respectivamente.

De acuerdo con otros estudios panel, para el examen de las finanzas públicas municipales del Estado de Oaxaca construimos una base con pocos datos anuales pero con un número amplio de municipios (570) - el mayor número en toda la República Mexicana- lo que asegura una estimación de los parámetros consistente. El modelo específicado en (1) también incluye los siguientes supuestos: $\mathrm{E}\left(e_{i, t}\right)=0$ y $\mathrm{E}\left(e_{i}, e_{i, t}\right)=W_{i}$. El VAR con datos Panel se estima empleando el Método Generalizado de Momentos $(\mathrm{GMM})$ y la rutina desarrollada por Inessa Love ${ }^{6,7}$.

Una de las bondades del análisis de Vectores Autorregresivos es la posibilidad de examinar las Funciones de Impulso Respuesta (FIR) y el análisis de varianza; lo que no permite hacer la metodología de datos panel estándar. El VAR con datos panel empleado en este estudio nos permite realizar este tipo de examen e incluso calcular errores estándar mediante simulaciones de Monte Carlo con bandas al $5 \%$ y $95 \%$. La identificación del modelo emplea la descomposición de Choleski. differentiation would induce bias in the parameters estimated. To avoid this problem and ensure the orthogonality between the fixed effects and the lags of the variables, in our econometric exercise we use advanced differentiation compared to the mean, known as the Helmert, de Arellano and Bover procedure $(1995)^{5}$.

The extension of the ARV model with panel data that we propose here considers in addition the possibility of the municipalities of the state of Oaxaca being affected in a common way in specific points in time. This possibility is measured by $d_{t}$ approaching the impact of macro regional economic effects shared by all the municipalities that are not included in $z_{i, t}$ or any of their lags. In this case, the fixed effect is eliminated applying deviations of each variable compared to the mean for each municipality and year respectively.

According to other panel studies, for the exam of municipal public finances from the state of Oaxaca we build a base with few annual data but with ample number of municipalities (570) - the highest number in the whole Mexican Republic- which ensures a consistent estimation of the parameters. The model specified in (1) also includes the following assumptions: $\mathrm{E}\left(e_{i, t}\right)=0$ and $\mathrm{E}\left(e_{i}, e_{i, t}\right)=W_{i}$. The ARV with panel data is estimated by using the Generalized Moments Method (GMM) and the routine developed by Inessa Love ${ }^{6,7}$.

One of the advantages of the analysis of Autoregressive Vectors is the possibility of examining the Functions of Impulse Response (FIR) and the variance analysis, which the standard methodology of panel data does not allow doing. The ARV with panel data used in this study allows us to perform this type of exam and even to calculate standard errors through Monte Carlo simulations with $5 \%$ and $95 \%$ bands. The identification of the model uses the Choleski decomposition.

\section{EXPLORATORY ANALYSIS OF THE DATA AND RESULTS}

The data used in this study utilize statistics provided by the Ministry of Finances of the Free and Sovereign State of Oaxaca. The consistency of all the data and the comparability with the public information available reported by the National Institute of Statistics and Geography (Instituto 


\section{ANÁLISIS EXPLORATORIO DE LOS DATOS Y RESULTADOS}

Los datos empleados en este estudio utilizan estadísticas provistas por la Secretaría de Finanzas del Gobierno del Estado Libre y Soberano de Oaxaca. Se verificó la consistencia de todos los datos y la comparabilidad con la información pública disponible reportada por el Instituto Nacional de Estadística y Geografía (INEGI) y la Secretaría de Hacienda y Crédito Público (SHCP). El Estado de Oaxaca cuenta con 570 municipios de los que obtuvimos información sobre aportaciones, participaciones e ingresos propios (predial y agua) a precios corrientes para el periodo 2002-2010. Con estos datos se formó un panel balanceado que contiene en total 5,130 observaciones. Las variables nominales fueron deflactadas con el Índice Nacional de Precios al Consumidor (INPC) y se calcularon valores per cápita a precios constantes del año 2010. El Producto Interno Bruto (PIB) municipal se calculó siguiendo la metodología de Sánchez Almanza (2000) y Unikel (1976), empleada también por Ibarra y Sotres (2009) en los municipios del estado de Tamaulipas.

También se tipifica a los municipios de acuerdo con el régimen político que siguen, a saber si se rigen bajo el principio de 'usos y costumbres'. Esta es la primera vez que un estudio distingue esta característica en el examen de la asociación entre esfuerzo fiscal y transferencias federales en México.

\section{Estadística descriptiva}

El Cuadro 1 muestra estadística descriptiva de las variables bajo estudio en valores per cápita distinguiendo el origen político de los ayuntamientos. En particular se observa que la mayor parte de los municipios sigue un régimen de usos y costumbres (418 de 570). Los municipios regidos por usos y costumbres (UyC) recaudan en promedio mucho menos recursos fiscales por cada habitante que municipios elegidos por partidos. Es evidente que estos promedios subvaloran el comportamiento de los ingresos si consideramos la magnitud de la desviación estándar, que en realidad sugiere que hay algunos municipios con niveles recaudatorios mucho mayores entre ellos la capital del estado (Oaxaca de Juárez), seguidos por Santa María Huatulco, San Juan Bautista Tuxtepec y
Nacional de Estadistica y Geografia, INEGI) and the Ministry of Finance (Secretaria de Hacienda y Crédito Público, SHCP) was verified. The state of Oaxaca has 570 municipalities from which we obtained information about contributions, participations and income of their own (property and water taxes) at current prices for the period 2002-2010. With these data a balanced panel was formed that contains in total 5,130 observations. The nominal variables were deflated with the National Consumer Price Index (Indice Nacional de Precios al Consumidor, INPC) and per capita values were calculated at constant prices of the year 2010. The municipal Gross Domestic Product (GDP) was calculated following the methodology by Sánchez Almanza (2000) and Unikel (1976), also used by Ibarra and Sotres (2009) in the municipalities of the state of Tamaulipas.

The municipalities are also typified according to the political regime that they follow, that is, whether they are ruled by the principle of 'uses and customs'. This is the first time that a study distinguishes this characteristic in the exam of the association between fiscal effort and federal transferences in Mexico.

\section{Descriptive statistics}

Table 1 shows the descriptive statistics of the variables under study in per capita values, distinguishing the political origin of the local governments. In particular, it is observed that the larger part of the municipalities follow a regime of uses and customs (418 of 570). The municipalities ruled by uses and customs (U\&C) collect in average much less fewer resources per inhabitant than municipalities chosen by parties. It is evident that these averages undervalue the behavior of the income if we consider the magnitude of the standard deviation, which actually suggests that there are some municipalities with much higher tax collection levels - among them the capital of the state (Oaxaca de Juárez), followed by Santa María Huatulco, San Juan Bautista Tuxtepec and Salina Cruz, among others. Such dispersion of the data also confirms the marked inequality of municipal income in the state of Oaxaca. While there are a very high proportion of municipalities that do not collect a single Peso (MXN), such as Santa María Texcaltitlán, Santiago Texcaltitlán, Santiago Atitlán, among many others, there are others that achieve an average collection 
Cuadro 1. Estadística descriptiva de variables fiscales en municipios regidos por usos y costumbres y por partidos políticos. Table 1. Descriptive statistics of fiscal variables in municipalities ruled by uses and customs, and by political parties.

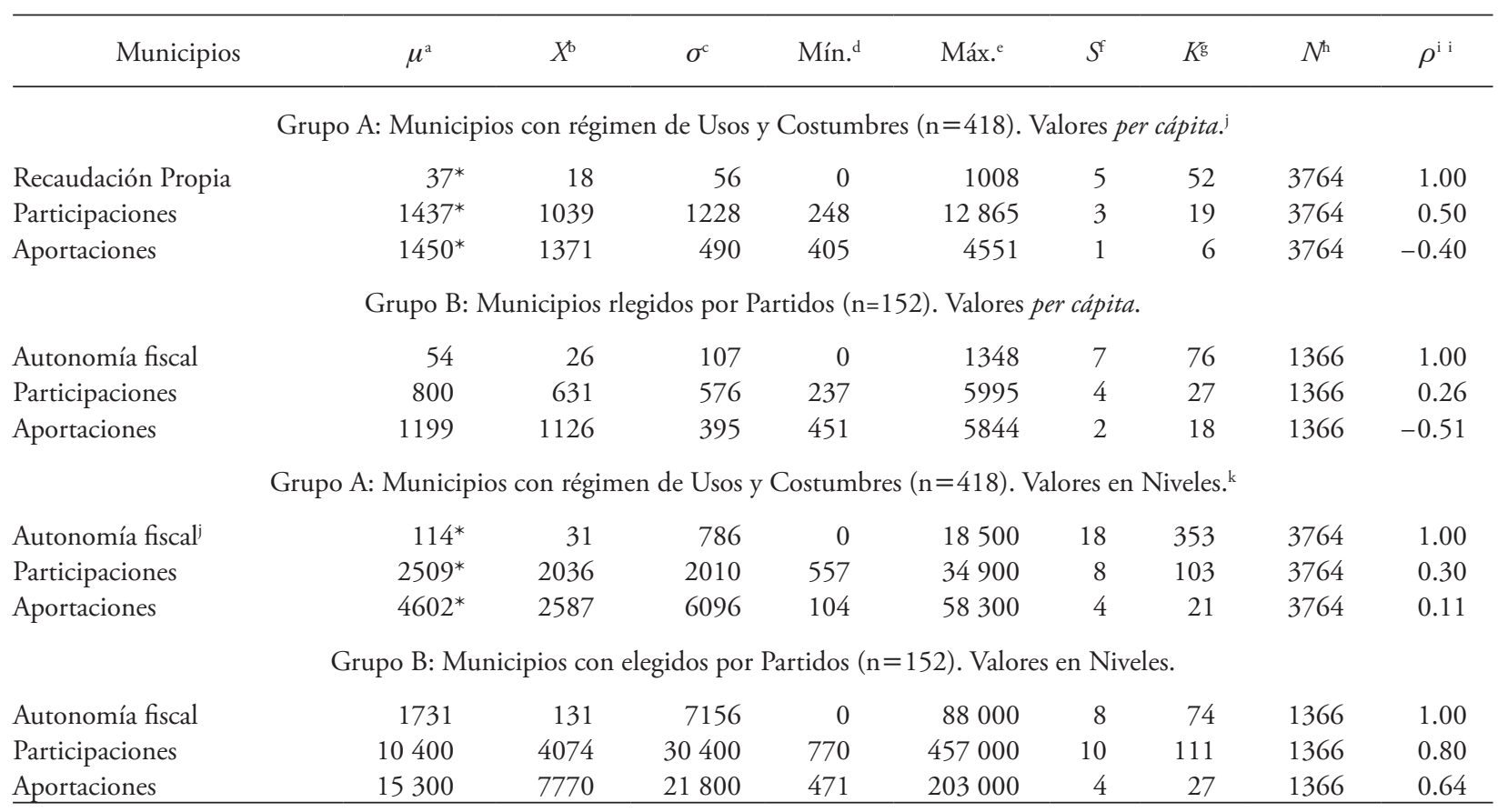

Fuente: cálculos propios en base al datos provistos por la Secretaría de Finanzas del Estado de Oaxaca. a $\mu$ : Promedio aritmético de los ingresos propios (predial y agua); b $X$ : mediana; c $\sigma$ : desviación estándar; d Mín: Mínimo; e Máx: Máximo; f $S$ : Sesgo; g K: Curtosis; h $N$ : número de observaciones, compuesto por $n$ municipios y T: tiempo; i $\rho$ : coeficiente de correlación entre esfuerzo fiscal y cada una de las variables fiscales, todos los valores significativos al 95\%; j Valores per cápita en Pesos Mexicanos; k Niveles en Miles de Pesos Mexicanos; * Prueba de hipótesis sobre diferencia de medias entre los valores de UyC contra los municipios democráticos. Diferencia significativa al $99 \%$. Source: author's calculations based on data provided by the Ministry of Finance of the state of Oaxaca. a $\mu$ : Arithmetic average of own income (property and water taxes); b X: median; c $\sigma$ : standard deviation; d Mín: Minimum; e Máx: Maximum; f S: Bias; g K: Kurtosis; h $N$ : number of observations, made up of $n$ municipalities and $T$ time; i $\rho$ : correlation coefficient between fiscal effort and each one of the fiscal variables, all significant values at 95\%; $\mathrm{j}$ Values per capita in Mexican Pesos; $\mathrm{k}$ Levels in Thousands of Mexican Pesos; * Hypothesis test of difference of means between values of U\&C versus democratic municipalities. Significant difference at $99 \%$.

Fuente: elaboración propia con datos de la Secretaría de Finanzas del Gobierno del Estado de Oaxaca. \& Source: author's elaboration with data from the Ministry of Finance of the state of Oaxaca.

Salina Cruz, entre otros. Tal dispersión de los datos confirma también la marcada desigualdad de ingresos propios en el Estado de Oaxaca. Mientras que existe una proporción muy alta de municipios que no recaudan un solo Peso (MXN) como Santa María Texcaltitlán, Santiago Texcaltitlán, Santiago Atitlán entre muchos otros, existen otros que logran una recaudación promedio de hasta MXN $\$ 88$ millones de pesos (niveles a precios de 2010).

Entre las hipótesis que buscamos probar se encuentra sí los municipios con usos y costumbres reciben mayores transferencias federales que aquellos municipios elegidos de manera democrática. Aunque en niveles el monto promedio de transferencias recibidas por municipios elegidos por partidos políticos of up to MXN \$ 88 million pesos (levels at 2010 prices).

Among the hypotheses that we seek to test is whether the municipalities with uses and customs receive higher federal transferences than those municipalities chosen democratically. Although in levels the average amount of transferences received by municipalities chosen by political parties is higher, Table 1 shows that in per capita terms, the municipalities chosen by U\&C have received in average higher amounts of transferences than the municipalities chosen by the political party system. In the case of the participations, which are distributed in function of the population component and of municipal income, the difference in favor 
es mayor, en el Cuadro 1 se observa que en términos per cápita los municipios elegidos por $\mathrm{UyC}$ han recibido en promedio montos de transferencias mayores que los municipios elegidos por el sistema de partidos políticos. En el caso de las participaciones, que se distribuyen en función del componente poblacional $\mathrm{y}$ de los ingresos propios, la diferencia a favor de municipios regidos por usos y costumbres es en promedio casi el doble.

Este promedio sin embargo esconde la tendencia histórica de las transferencias a los municipios del Estado de Oaxaca. En la Figura 1 mostramos el comportamiento de las participaciones y de las aportaciones a los municipios de Oaxaca distinguiendo el origen político. Es claro que en los dos tipos de transferencias, los montos per cápita (a precios de 2010) han sido históricamente mayores para los municipios de $\mathrm{UyC}$ que para los municipios elegidos por el sistema de partidos. Esta observación acumula evidencia a favor de la hipótesis de integración, en la que se sugiere que las transferencias son mayores para municipios disidentes y tienen el fin de mantener la cohesión, más que incentivar la recaudación propia (la cual como hemos visto es más baja en estos municipios).

La última columna del Cuadro 1 muestra una relación positiva entre los ingresos propios per cápita de los municipios y las participaciones per cápita, mientras que revelan una relación negativa con las aportaciones per cápita. Municipios regidos por usos y costumbres tienen una correlación positiva más fuerte

Participación per cápita

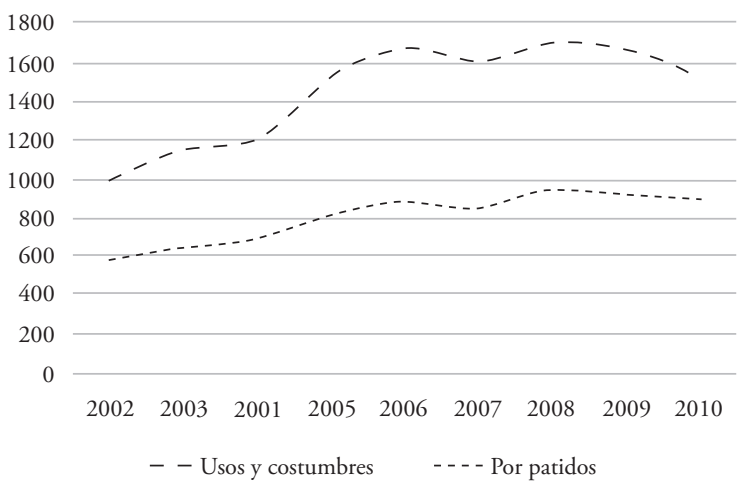

of municipalities ruled by uses and customs is, in average, almost double.

This average, however, hides the historical trend of transferences to the municipalities of the state of Oaxaca. Figure 1 shows the behavior of the participations and the contributions to the municipalities of Oaxaca, differentiating the political origin. It is clear that in the two types of transferences, the amounts per capita (at 2010 prices) have been historically higher for the U\&C municipalities than for the municipalities chosen by the political party system. This observation accumulates evidence in favor of the integration hypothesis, where it is suggested that the transferences are higher for dissident municipalities and have the aim of maintaining cohesion, rather than stimulating their own tax collection (which, as we have seen, is lower in these municipalities).

The last column of Table 1 shows a positive relation between the per capita income of the municipalities and the per capita participations, while they reveal a negative relation with the per capita contributions. Municipalities ruled by uses and customs have a stronger positive correlation with the participations $(r=0.5)$ than the one observed in municipalities chosen democratically $(r=0.26)$; meanwhile, the contributions are related negatively and to a greater degree with municipalities ruled democratically $(r=-0.51)$ than with municipalities ruled by uses and customs $(r=-0.40)$.

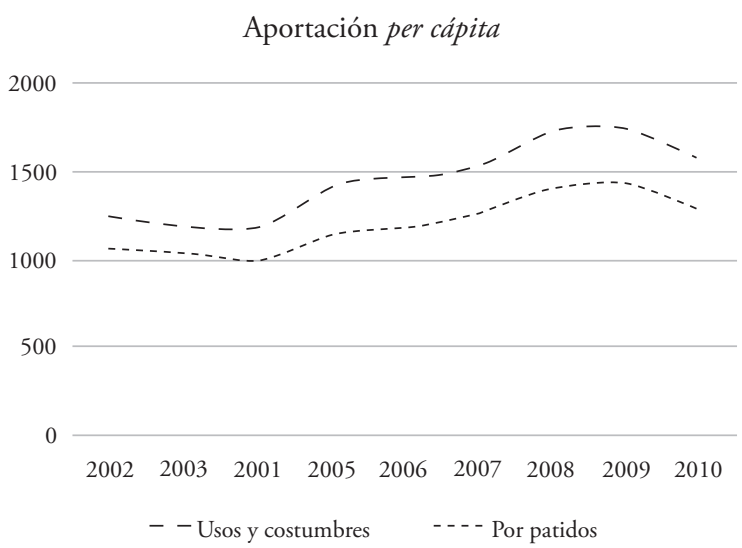

Fuente: elaboración propia con datos de la Secretaría de Finanzas del Estado de Oaxaca (2011). * Source: author's elaboration with data from the Ministry of Finance of the state of Oaxaca (2011).

Figura 1. Transferencias per cápita por tipo de transerencia, (Pesos MXN, 2010=100).

Figure 1. Per capita transferences per type of transference, (Pesos MXN, 2010=100). 
con las participaciones $(r=0.5)$ que la que se observa en municipios elegidos democráticamente $(r=0.26)$; mientras que las aportaciones se relacionan negativamente y en mayor medida con municipios regidos democráticamente $(r=-0.51)$ que con municipios regidos por usos y costumbres $(r=-0.40)$.

La estadística descriptiva muestra rasgos interesantes del sistema federal fiscal y las condiciones político democráticas de los municipios del Estado de Oaxaca. En particular, encontramos en este primer acercamiento que los municipios regidos por usos y costumbres recaudan menos ingresos propios y que estos a su vez han recibido mayores montos de transferencias per cápita en promedio en el periodo de estudio (2002-2010). La recaudación propia se relaciona de manera positiva con las participaciones, pero de manera negativa con las aportaciones.

Sin embargo, hasta este punto no podemos establecer relación causal entre la recaudación propia y las transferencias y tampoco tenemos una idea acerca de si las transferencias son persistentes y por cuánto tiempo. Es necesario integrar la interacción dinámica de las participaciones, las aportaciones y los ingresos propios municipales. En la siguiente subsección estimamos el VAR con datos panel presentado en la sección anterior que permite modelar precisamente varias características de interés, a saber, las relaciones de causalidad entre las variables, la persistencia, la fuerza de las relaciones, etcétera.

\section{Resultados}

En este trabajo buscamos documentar evidencia sobre la posibilidad de que un gobierno central busque mantener la cohesión de los municipios utilizando transferencias, por lo que las transferencias federales pueden ser empleadas como mecanismos de compensación, estabilidad e integración política más que como instrumentos para generar incentivos sobre la recaudación de los municipios como en Inman y Rubinfeld, (1997); Bolton y Roland (1997); LeiteMonteiro y Sato (2003); Sato (2007), privilegiando el sentido distributivo y descuidando el sentido resarcitorio de las mismas, (Peña, J. y L. Wence, 2011).

Evidencia a favor de esta hipótesis de integración puede provenir de observar, primero, un mayor monto de transferencias federales a municipios regidos por usos y costumbres y, segundo, una disociación entre las transferencias y la capacidad de incentivar
The descriptive statistics show interesting features of the federal fiscal system and the political democratic conditions of the municipalities in the state of Oaxaca. In particular, we find in this first approach that the municipalities ruled by uses and customs collect less income of their own and that these in turn have received higher amounts of per capita transferences in average in the study period (2002-2010). The tax collection of their own is related positively with the participations, but negatively with the contributions.

However, up to this point we cannot establish a causal relation between their own tax collection and transferences, and we also do not have an idea about whether the transferences are persistent and for how long. It is necessary to integrate the dynamic interaction of participations, contributions, and municipal income. In the following subsection, we estimate the ARV with the panel data presented in the previous section which allows modelling accurately several characteristics of interest, namely, the causality relationships between variables, the persistence, the strength of relations, etc.

\section{Results}

In this study we seek to document evidence about the possibility of a central government looking to maintain the cohesion of municipalities using transferences, which is why the federal transferences can be used a mechanisms for compensation, stability and political integration, rather than as instruments to generate incentives for tax collection by municipalities, as proposed by Inman and Rubinfeld, (1997); Bolton and Roland (1997); Leite-Monteiro and Sato (2003); Sato (2007), privileging the distributive sense and neglecting the compensating sense of the transferences (Peña, J. and L. Wence, 2011).

Evidence in favor of this hypothesis of integration can come from observing, first, a higher amount of federal transferences to municipalities ruled by uses and customs and, second, dissociation between transferences and the capacity to stimulate higher tax collection of their own. The descriptive statistics suggest that the municipalities ruled by uses and customs have received in average higher amounts of transferences per capita. It is also seen that tax collection of their own per capita is related positively with the participations, but negatively with the contributions. However, up to this point we cannot determine the causal direction 
mayor recaudación propia. La estadística descriptiva sugiere que los municipios regidos por usos y costumbres han recibido en promedio mayores montos de transferencias per cápita. También se encuentra que la recaudación propia per cápita se relaciona de manera positiva con las participaciones, pero de manera negativa con las aportaciones. Sin embargo, hasta este punto no podemos determinar la dirección causal de la recaudación propia y las transferencias por lo que enseguida determinamos el impacto dinámico de las transferencias federales (participaciones y aportaciones) sobre la recaudación propia de los municipios de Oaxaca.

Para municipios elegidos democráticamente, esperamos que un mayor monto de participaciones esté relacionado con mayores niveles de recaudación de los municipios (ingresos propios por predial y agua), como obtienen (Cárdenas y Sharma, 2011; Benton, 1992; Guadarrama, 2006, Moreno, 2003; Unda y Moreno, 2015). Esta relación esperada es así debido a que el monto que cada municipio recibe del Fondo de Fomento Municipal (FFM), un componente de las participaciones federales, depende de la recaudación local de predial y de los derechos de agua de dos ańos anteriores. En adición el Fondo Complementario del Fondo General de Participaciones (FGP) reparte al municipio participaciones adicionales en proporción al monto de la recaudación del Predial y los derechos de consumo de agua del año anterior. De manera similar, debido a que el monto de las aportaciones recibidas por cada municipio del Estado de Oaxaca depende de criterios distributivos, i.e., de la proporción de habitantes en cada uno de ellos, esperamos a priori una relación positiva entre aportaciones y la recaudación propia, como encuentran (Moreno, 2003; Unda y Moreno 2015).

El Cuadro 2 siguiente muestra los parámetros estimados del VAR de tercer orden con datos panel empleando el Método Generalizado de Momentos ${ }^{8}$. Se estimaron dos versiones del modelo (1) que corresponden al caso de los municipios regidos bajo el esquema de usos y costumbres (columna $a$ ) y los municipios con régimen de partidos políticos (columna $b$ ). Cada columna se divide en tres paneles que muestran el impacto promedio de los rezagos de cada variable per cápita sobre sí misma y sobre otras variables?

La relación dinámica entre las variables puede apreciarse parcialmente en el Cuadro 2, aunque en realidad la respuesta de la autonomía fiscal a choques of their own collection and transferences, so next we determine the dynamic impact of the federal transferences (participations and contributions) on the tax collection by municipalities of Oaxaca.

For municipalities chosen democratically, we expect that a higher amount of participations is related to higher levels of tax collection by the municipalities (income of their own from property and water taxes), as obtained by Cárdenas and Sharma (2011), Benton (1992), Guadarrama (2006), Moreno (2003), and Unda and Moreno (2015). This is the expected relation because the amount that each municipality receives from the Municipal Promotion Fund (Fondo de Fomento Municipal, FFM), a component of federal participations, depends on the local collection of property taxes and from water rights of the two previous years. In addition, the Complementary Fund of the General Participations Fund (Fondo General de Participaciones, FGP) distributes to the municipalities additional participations in proportion to the amount of the property tax collection and the water consumption rights from the previous year. Similarly, because the amount of the contributions received by each municipality in the state of Oaxaca depends on distributive criteria, that is, on the proportion of inhabitants in each one of them, we expect a priori a positive relation between contributions and their own tax collection, as found by Moreno (2003), and Unda and Moreno (2015).

Table 2 shows the parameters estimated of the third-degree ARV with panel data using the Generalized Moments Method ${ }^{8}$. Two versions of the model (1) were estimated that correspond to the case of the municipalities ruled under the scheme of uses and customs (column $a$ ) and the municipalities with the political party regime (column $b$ ). Each column is divided into three panels that show the average impact of the lags from each per capita variable on itself and on other variables?

The dynamic relation between the variables can be partially appreciated in Table 2 , although in truth the response of fiscal autonomy to shocks from federal transferences is best appreciated with the functions of impulse response shown in Figure 2, divided into two panels that distinguish the cases of political origin listed above: Group A municipalities elected by U\&C and Group $B$ municipalities elected by parties. In each case the figures show in the principal diagonal the auto-responses of each variable to shocks from 
Cuadro 2. Recaudación propia, Participaciones y Aportaciones. ${ }^{2}$

Table 2. Own tax collection, Participations and Contributions. ${ }^{a}$

\begin{tabular}{|c|c|c|c|c|}
\hline & \multicolumn{2}{|c|}{ Usos y Costumbres (a) } & \multicolumn{2}{|c|}{ Democrático (b) } \\
\hline & $\square_{i, i}$ & Error Std. ${ }^{\mathrm{b}}$ & $\square_{i}$ & Error Std. ${ }^{\mathrm{b}}$ \\
\hline \multicolumn{5}{|c|}{ Grupo 1. Recaudación propia de los municipios (predial y agua) } \\
\hline Predial $_{t-1}$ & $0.6026^{*}$ & 0.1172 & $0.9012^{*}$ & 0.0913 \\
\hline Predial $_{t-2}$ & $0.2677^{*}$ & 0.0677 & 0.0072 & 0.0350 \\
\hline Predial ${ }_{t-3}$ & $-0.0700^{*}$ & 0.0202 & -0.0271 & 0.0191 \\
\hline Participa $_{\mathrm{t}-1}$ & $1.2127^{*}$ & 0.3250 & $0.4857^{*}$ & 0.1471 \\
\hline Participa $_{\mathrm{t}-2}$ & $-0.7797^{*}$ & 0.1586 & $-0.2315^{* *}$ & 0.1058 \\
\hline Participa $\mathrm{t}_{\mathrm{t}-3}$ & -0.3358 & 0.2872 & -0.0722 & 0.1438 \\
\hline Aporta $_{\mathrm{t}-1}$ & $-1.0261^{*}$ & 0.2336 & $-0.8059^{* *}$ & 0.3363 \\
\hline Aporta $_{\mathrm{t}-2}$ & $0.4983^{*}$ & 0.1715 & 0.1559 & 0.0975 \\
\hline Aporta $_{\mathrm{t}-3}$ & 0.3756 & 0.4361 & 0.2002 & 0.1462 \\
\hline \multicolumn{5}{|c|}{ Grupo 2. Participaciones a los municipios } \\
\hline Predial $_{t-1}$ & -0.0381 & 0.0269 & -0.0069 & 0.0412 \\
\hline Predial $t_{-2}$ & -0.0068 & 0.0098 & 0.0116 & 0.0137 \\
\hline Predial $_{t-3}$ & -0.0025 & 0.0041 & 0.0048 & 0.0105 \\
\hline Participa $_{\mathrm{t}-1}$ & $0.5595^{*}$ & 0.0983 & $0.6095^{*}$ & 0.0577 \\
\hline Participa $_{\mathrm{t}-2}$ & $0.3083^{*}$ & 0.0547 & $0.1570^{* *}$ & 0.0636 \\
\hline Participa $\mathrm{t}_{\mathrm{t}-3}$ & 0.1040 & 0.0870 & $0.1781^{* *}$ & 0.0778 \\
\hline Aporta $_{\mathrm{t}-1}$ & $-0.2090^{*}$ & 0.0580 & $-0.3566^{* *}$ & 0.1467 \\
\hline Aporta $_{\mathrm{t}-2}$ & $-0.6015^{*}$ & 0.0617 & $-0.2189^{* * *}$ & 0.1193 \\
\hline Aporta $_{\mathrm{t}-3}$ & 0.0612 & 0.1218 & -0.0831 & 0.0900 \\
\hline \multicolumn{5}{|c|}{ Grupo 3. Aportaciones a los municipios } \\
\hline Predial $_{t-1}$ & $-0.0410^{* *}$ & 0.0207 & -0.0189 & 0.0296 \\
\hline Predial $_{\mathrm{t}-2}$ & $0.0197^{* *}$ & 0.0080 & $0.0194^{* * *}$ & 0.0104 \\
\hline Predial $_{\mathrm{t}-3}$ & $-0.0195^{*}$ & 0.0037 & -0.0009 & 0.0064 \\
\hline Participa $_{\mathrm{t}-1}$ & $-0.3825^{*}$ & 0.0806 & $-0.2218^{*}$ & 0.0534 \\
\hline Participa $_{\mathrm{t}-2}$ & $0.3461^{*}$ & 0.0424 & $0.1351^{*}$ & 0.0467 \\
\hline Participa $\mathrm{t}_{\mathrm{t}-3}$ & $0.2153^{*}$ & 0.0707 & $0.2550^{*}$ & 0.0619 \\
\hline Aporta $_{\mathrm{t}-1}$ & $0.6240^{*}$ & 0.0518 & $0.4793^{*}$ & 0.1130 \\
\hline Aporta $_{\mathrm{t}-2}$ & $-0.4132^{*}$ & 0.0500 & $-0.1599^{* * *}$ & 0.0831 \\
\hline Aporta $_{t-3}$ & -0.1580 & 0.1013 & $-0.2068^{*}$ & 0.0709 \\
\hline
\end{tabular}

***, ${ }^{* * *}$ denota significancia a niveles de $1 \%, 5 \%$ y $10 \%$. a Estimaciones VAR Panel por el Método Generalizado de Momentos (GMM). Variables transformadas mediante el método Helmert de Arellano y Bover (1995). Modelos justamente identificados de acuerdo con la $J$ de Hansen. b Errores std. ajustados por heteroscedasticidad frente a cada grupo. * ***, *** denotes significance at levels of $1 \%$, $5 \%$ and 10\%. a ARV Panel estimations by the Generalized Moments Method (GMM). Variables transformed through the Helmert de Arellano and Bover method. Models identified precisely according to the Hansen J. b Standard errors adjusted by heteroscedasticity in face of each group.

Fuente: elaboración propia con datos de la Secretaría de Finanzas del Gobierno del Estado de Oaxaca. \&ource: author's elaboration with data from the Ministry of Finance of the Government of the state of Oaxaca.

provenientes de las transferencias federales se aprecia mejor con las funciones de impulso respuesta mostradas en la Figura 2, dividida en dos paneles que distinguen los casos de origen político arriba listados: Grupo A municipios elegidos por UyC y Grupo $B$ Municipios elegidos por partidos. En cada caso las figuras muestran en la diagonal principal las autorespuestas de cada variable a choques provenientes de themselves; and in the figures outside the diagonal the responses from each one of them to shocks from other variables.

\section{Fiscal effort and federal transferences}

In the first place, it is generally confirmed that shocks that come from the equation of participations 
sí mismas; y en las figuras fuera de la diagonal las respuestas de cada una de ellas a choques provenientes de otras variables.

\section{El esfuerzo fiscal y las transferencias federales}

En primer término se confirma en general que choques provenientes de la ecuación de participaciones ejercen un impacto positivo y persistente sobre la recaudación propia de los municipios (ver figura central superior en los Grupos A y B). Esta respuesta positiva esperada de los ingresos propios a choques provenientes de las participaciones se registra de manera significativa (al 95\%) para los municipios regidos por usos y costumbres (grupo $a$ ). Aún cuando la respuesta inicial es nula, el esfuerzo recaudatorio se incrementa en los ańos siguientes. La persistencia de los choques de participaciones sobre la recaudación propia de los municipios regidos por UyC es de dos años. Es decir, además de que las participaciones pueden dirigirse a mantener la estabilidad política de estos municipios, inercias positivas exert a positive and persistent impact on tax collection by municipalities (see central upper figure in Groups $\mathrm{A}$ and $\mathrm{B}$ ). This expected positive response from their own income to shocks from the participations is recorded significantly (at $95 \%$ ) for the municipalities ruled by uses and customs (group $a$ ). Even when the initial response is null, the tax collection effort increases in the next years. The persistence of the shocks from participations on tax collection by the municipalities ruled by $\mathrm{U} \& \mathrm{C}$ is two years. That is, in addition to the participations being directed to maintaining the political stability of these municipalities, additional positive inertias stimulate the tax collection by these municipalities in the short term ${ }^{10}$.

In contrast, shocks from the equation of contributions have a negative and significant impact on the municipalities (see upper right figure, groups (A)-(B) of graph 2 , respectively). The impact turns out to be of higher magnitude and more persistent (lasting almost four years) for the case of the municipalities ruled by uses and customs. This result suggests that, in contrast to the municipalities

Grupo A: Municipios elegidos por Usos y Costumbres.
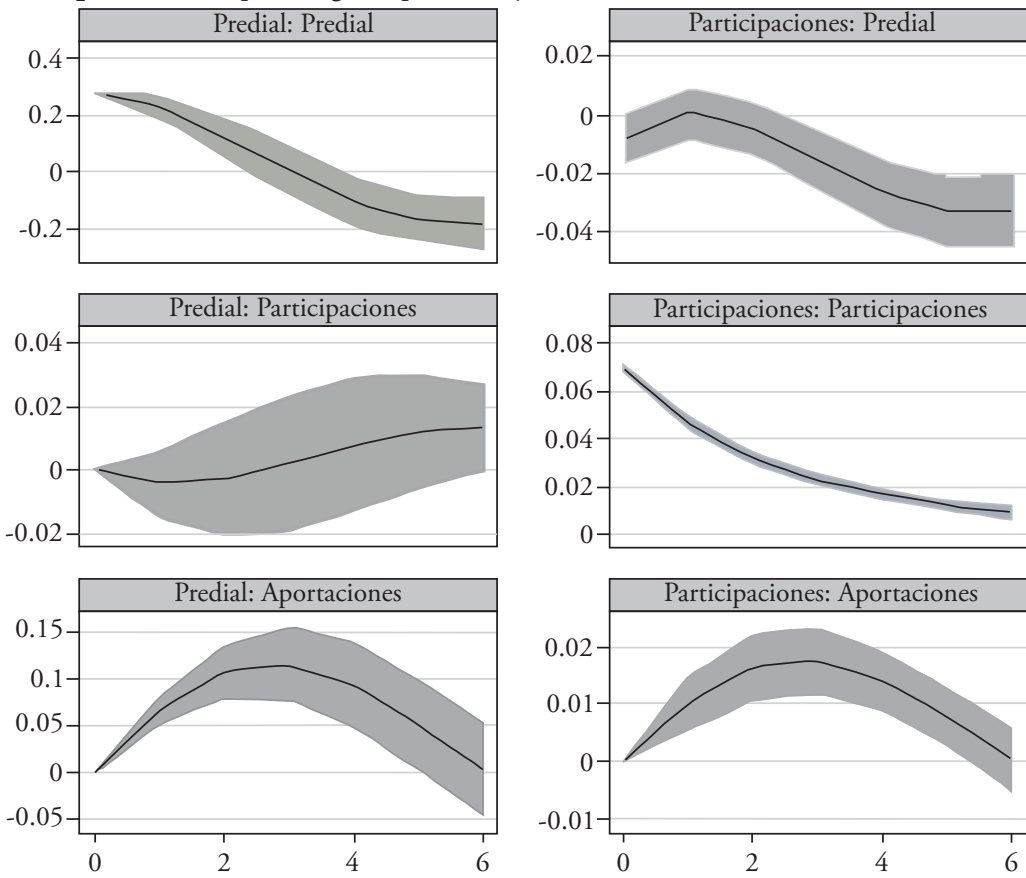

Periodos de impacto
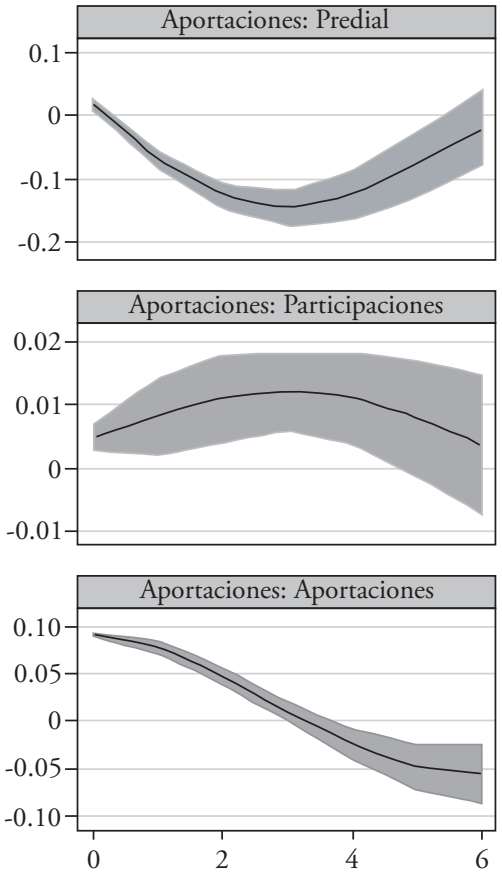

Funciones del Impulso Respuesta Ortogonalizadas

Impulso: respuesta 
Grupo B: Municipios elegidos Democráticamente.
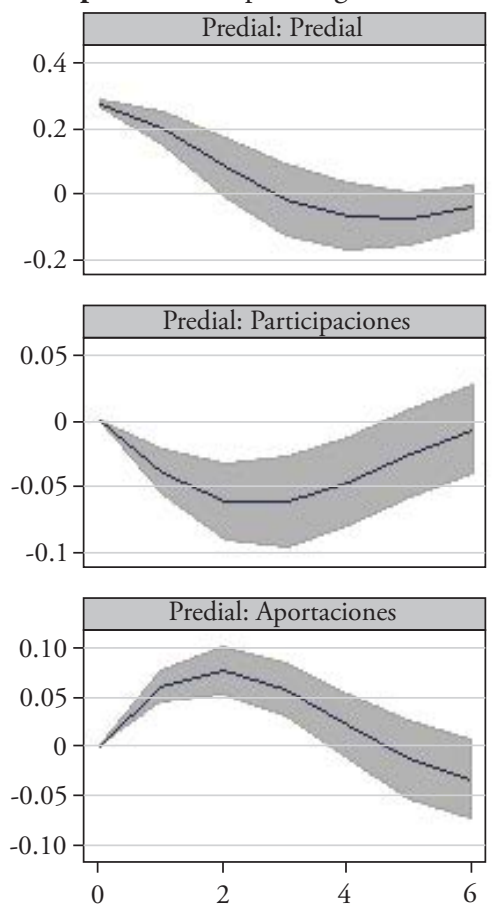

$90 \%$ IC
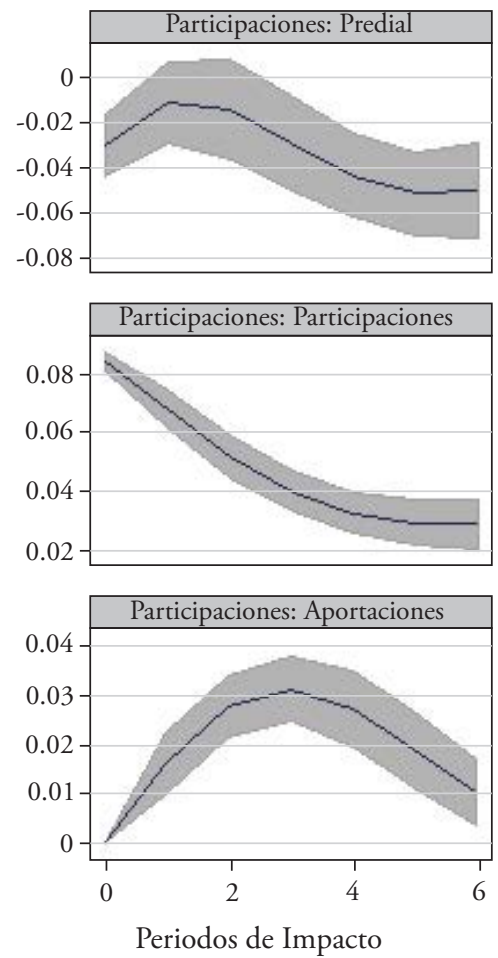

Funciones de Impulso Respuesta
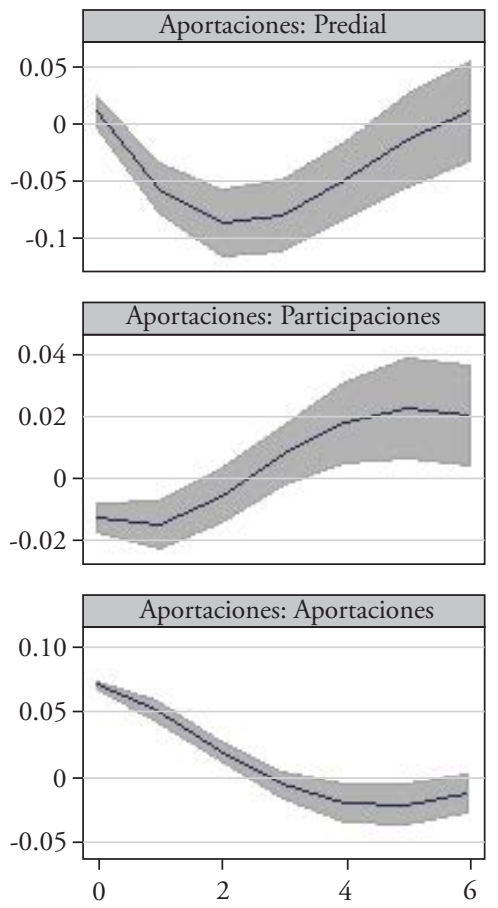

Impulso: respuesta

Fuente: elaboración propia con base en datos de la Secretaría de Finanzas del Estado de Oaxaca. * Source: author’s elaboration based on data from the Ministry of Finance of the state of Oaxaca.

Figura 2: Funciones de Impulso Respuesta del VAR con Datos Panel.

Figure 2: Functions of Impulse Response of the ARV with Panel Data.

adicionales incentivan la recaudación propia de estos municipios en el corto plazo ${ }^{10}$.

En contraste, choques provenientes de la ecuación de aportaciones tienen un impacto negativo y significativo sobre los municipios (ver figura superior derecha, grupos (A)-(B) de la gráfica 2 respectivamente). $\mathrm{El}$ impacto resulta de mayor magnitud y más persistente (duración de casi cuatro años) para el caso de los municipios regidos por usos y costumbres. Este resultado sugiere que, a diferencia de los municipios elegidos democráticamente, aún cuando las aportaciones puedan reforzar la cohesión y estabilidad política de estos municipios, inercias asociadas con este tipo de transferencias desinhiben el esfuerzo fiscal de los municipios [regularidad también reportada en otros estudios como el de Moreno (2003) y Sour $(2004,2008)]^{11}$. La asociación negativa entre esfuerzo fiscal y aportaciones puede reflejar la existencia de chosen democratically, even when the contributions can reinforce the political cohesion and stability of these municipalities, inertias associated with this type of transferences disinhibit the fiscal effort of the municipalities [regularity also reported in other studies such as those by Moreno (2003) and Sour $(2004,2008)]^{11}$. The negative association between fiscal effort and contributions can reflect the existence of a hold-up problem, where municipalities decrease the tax collection effort when facing the expectation of lower future transferences—see Zhuravskaya (2000). The latter is consistent with what was established by Hernández and Jarillo (2007), regarding the amount of the Fund for Contributions for Municipal Infrastructure (Fondo de Aportaciones para la Infraestructura Municipal, FISM), which municipalities receive, being influenced by the marginalization index of the municipality. 
un problema de interrupción (hold-up problem), en el que los municipios disminuyen el esfuerzo recaudatorio ante la expectativa de menores transferencias futuras-ver Zhuravskaya (2000). Esto último es consistente con lo establecido por Hernández y Jarillo (2007), acerca de que el monto del Fondo de Aportaciones para la Infraestructura Municipal (FISM), que reciben los municipios, es influido por el índice de marginación del municipio.

\section{Sustitución Participaciones y Aportaciones Municipales}

Ahora examinamos la relación dinámica entre las participaciones y las aportaciones municipales. En general, se observa que la respuesta de las participaciones a choques ortogonales provenientes de ecuación de aportaciones es negativa, significativa y altamente persistente (ver figura central de la última columna en cada grupo). Los factores inesperados que determinan la dinámica de las aportaciones a los municipios del Estado de Oaxaca inhiben la respuesta de las participaciones por periodos de tiempo prolongados, en ningún caso menores a seis años. Esta respuesta parece más pronunciada en los municipios regidos por usos y costumbres. En resumen, los choques de aportaciones no solo afectan negativamente el esfuerzo recaudatorio de los municipios del Estado de Oaxaca, sino que también desinhiben la dinámica de las participaciones; de manera más intensa en municipios regidos por $\mathrm{UyC}$.

Por su parte, la respuesta de las aportaciones a choques provenientes de la ecuación de participaciones es positiva en el corto y largo plazo (ver figura inferior de la segunda columna en cada grupo). En un primer momento, justo después del choque, la respuesta de las aportaciones es positiva, i.e., choques positivos de participaciones alientan mayores montos de aportaciones. Sin embargo, la respuesta se torna no significativa para el mediano plazo (entre el primero y tercer año) y después responden positivamente en el largo plazo (del tercer año en adelante). Es decir, mayores participaciones alientan mayores montos de aportaciones con el tiempo en los dos grupos de municipios.

\section{Autorespuestas}

Respecto a la respuesta de las variables a choques provenientes de sí mismas, encontramos que

\section{Substitution of participations and municipal contributions}

Now we examine the dynamic relationship between the participations and the municipal contributions. In general, it is observed that the response of the participations to orthogonal shocks from the equation of contributions is negative, significant and highly persistent (see central figure of the last column in each group). The unexpected factors that define the dynamic of the contributions to municipalities of the state of Oaxaca inhibit the response of the participations by prolonged periods of time, in no case under six years. This response seems more pronounced in the municipalities ruled by uses and customs. In sum, the shocks from contributions not only affect negatively the tax collection effort of the municipalities of the state of Oaxaca, but they also disinhibit the dynamic of the participations, more intensely in municipalities ruled by U\&C.

In their turn, the response from contributions to shocks from the equation of participations is positive in the short and long term (see lower figure from the second column in each group). In a first moment, right after the shock, the response from the contributions is positive, that is, positive shocks from participations encourage higher amounts of contributions. However, the response turns nonsignificant for the medium term (between the first and third year) and then they respond positively in the long term (from the third year onward). That is, higher participations encourage higher amounts of contributions with time in the two groups of municipalities.

\section{Auto-responses}

Concerning the response of the variables to shocks from themselves, we find that in every case there is a positive, persistent and significant response (see the main diagonal of figures in each group, figure 2). The magnitude of the auto-response of the fiscal effort (upper left figure) is higher than that of the transferences. In particular, regarding the municipalities ruled by uses and customs, we observe that the auto-response of the fiscal effort is initially higher, although it decreases more rapidly and is more unstable than the auto-response of 
en todos los casos existe una respuesta positiva, persistente y significativa (ver la diagonal principal de figuras en cada grupo, Figura 2). La magnitud de la auto-respuesta del esfuerzo fiscal (figura superior izquierda) es mayor que la de las transferencias. En particular, respecto a los municipios regidos por usos y costumbres, observamos que la auto-respuesta del esfuerzo fiscal es inicialmente mayor, aunque decae más rápido y es más inestable que la auto-respuesta de los municipios elegidos democráticamente. Esto puede indicar que todos aquellos factores de choque que explican la recaudación propia no promueven un comportamiento estable de la recaudación de los municipios regidos por $\mathrm{UyC}$, mientras que en los municipios democráticos, esos mismos factores de choque estabilizan el comportamiento del esfuerzo fiscal e, incluso, lo hacen más persistente.

Por su parte, la auto-respuesta de las participaciones es más persistente que la auto-respuesta de las aportaciones (aproximadamente seis contra dos años). Mientras que los factores de choque que explican el comportamiento de las participaciones promueven su persistencia, en el caso de las aportaciones tales factores impactan de manera positiva, pero solo en corto plazo. A su vez, ni el nivel ni la persistencia de las participaciones o aportaciones se ven afectadas por el origen político de los municipios.

\section{CONCLUSIONES}

En este trabajo investigamos la relación fiscal entre la federación y las fuerzas políticas locales desde el enfoque positivo de la economía política. Se examinan las hipótesis de maquinaria política (machine politics), voto indeciso (swing vote) e integración política. La evidencia encontrada no parece fundamentar que las transferencias se dirijan a grupos de soporte político, ni tampoco buscan respaldo de regiones con votos indecisos. Sin embargo, lo que puede observarse es que municipios con poca cohesión al pacto federalista reciben una mayor monto de transferencias y que estas son persistentes (transferencias altas tienden a mantenerse así por periodos largos). Esta observación en particular refuerza la evidencia a favor de la hipótesis de integración, la cual sugiere que un gobierno central puede utilizar las transferencias para mantener la estabilidad y cohesión política de las regiones, es decir, como instrumentos para asegurar la cooperación e integración política, de manera similar the municipalities chosen democratically. This can indicate that all those shock factors that explain tax collection of their own do not promote a stable behavior of the collection in municipalities ruled by $\mathrm{U} \& \mathrm{C}$, while in the democratic municipalities, these same shock factors stabilize the behavior of the fiscal effort, and they even make it more persistent.

In its turn, the auto-response of the participations is more persistent than the auto-response of the contributions (approximately six versus two years). While the shock factors that explain the behavior of the participations promote their persistence, in the case of the contributions these factors impact positively, but only in the short term. In turn, neither the level nor the persistence of the participations or contributions are affected by the political origin of the municipalities.

\section{CONCLUSIONS}

In this study we research the fiscal relation between the federation and the local political forces from the positive approach of political economy. The hypotheses examined are machine politics, swing vote and political integration. The evidence found does not seem to support for transferences to be directed at groups of political support, and they also do not seek backing from regions with indecisive votes. However, what can be seen is that municipalities with low cohesion to the federalist pact receive a higher amount of transferences and that these are persistent (high transferences tend to manifest for long periods). This observation in particular reinforces the evidence in favor of the hypothesis of integration, which suggests that a central government can use transferences to maintain the stability and political cohesion of the regions, that is, as instruments to ensure political cooperation and integration, in a similar manner than authors such as Inman and Rubinfeld (1997), Sato (2007), and Leite-Monteiro and Sato (2003).

To examine this hypothesis of integration, we took advantage of the political configuration of one of the few regions where the procedure of uses and customs (U\&C) is used to elect local governments, an alternative constitutional figure to the traditional partisan struggle. In the first place, we observed that the municipalities ruled by $\mathrm{U} \& \mathrm{C}$ have received in average higher amounts of transferences percapita than the municipalities chosen by political parties. Also, 
que autores como (Inman y Rubinfeld, 1997; Sato 2007; Leite-Monteiro y Sato, 2003).

Para examinar esta hipótesis de integración aprovechamos la conformación política de una de las pocas regiones en donde se emplea el procedimiento de usos y costumbres ( $\mathrm{UyC}$ ) para elegir ayuntamientos, una figura constitucional alterna a la pugna partidista tradicional. En primer término, observamos que los municipios regidos por $\mathrm{UyC}$ han recibido en promedio mayores montos de transferencias per cápita que los municipios elegidos por partidos políticos. También, que choques de aportaciones impactan negativamente la recaudación propia de los municipios, independientemente de su origen político. Estos resultados también han sido encontrados en los trabajos de (Bolton y Roland, 1997; Alesina y Spolaore, 1997; Zhuravskaya, 2000; Unda y Moreno, 2015). Interpretamos una mayor recaudación propia y un asociación negativa con las aportaciones, como evidencia a favor de la hipótesis de integración en la que las transferencias pueden emplearse como instrumentos de cohesión socio-política, más que como incentivos de la autonomía municipal como en el estudio de (Inman y Rubinfeld, 1997). Este es particularmente el caso de los municipios regidos por UyC.

Por su parte, encontramos que choques provenientes de las participaciones impactan de manera positiva la recaudación propia de los municipios regidos por UyC, el efecto sin embargo es débil y poco persistente; mientras que el mismo impacto sobre el esfuerzo de los municipios regidos por partidos no es estadísticamente distinto de cero ${ }^{12}$. En términos netos en este estudio registramos evidencia a favor de la hipótesis de integración: el efecto positivo de choques de participaciones es compensado por el impacto negativo y mayor persistencia de choques de las aportaciones sobre la recaudación propia ${ }^{13}$.

Entre otros resultados también observamos que la recaudación per cápita propia de los municipios elegidos por partidos políticos es mayor que la de los municipios elegidos por Usos y Costumbres (UyC). Adicionalmente, encontramos que la dinámica de la recaudación propia de los municipios regidos por partidos es mucho más estable y persistente que los municipios emanados por UyC. Los ayuntamientos elegidos por UyC parecen mostrar efectivamente funciones fiscales objetivo distintas a los municipios regidos por partidos. Este resultado es consistente con lo reportado por Wittman (1995), quien observa que that shocks from contributions impact negatively the tax collection by municipalities, regardless of their political origin. These results have also been found in studies by Bolton and Roland (1997), Alesina and Spolaore (1997), Zhuravskaya (2000), and Unda and Moreno (2015). We interpret a higher tax collection of their own and a negative association with the contributions, as evidence in favor of the hypothesis of integration where transferences can be used as instruments of sociopolitical cohesion, rather than as incentives of municipal autonomy, as in the study by Inman and Rubinfeld (1997). This is in particular the case of municipalities ruled by U\&C.

In turn, we find that shocks from the participations impact positively tax collection by municipalities ruled by $U \& C$, the effect however is weak and slightly persistent, while the same impact on the effort of the municipalities ruled by parties is not statistically different from zero ${ }^{12}$. In net terms in this study we find evidence in favor of the hypothesis of integration; the positive effect of shocks from participations is compensated by the negative impact and higher persistence of shocks from contributions on the tax collection by municipalities ${ }^{13}$.

Among other results, we also observe that the tax collection per capita by the municipalities elected by political parties is higher than that of municipalities elected by Uses and Customs (U\&C). Additionally, we find that the dynamic of the tax collection by municipalities ruled by parties is much more stable and persistent than the municipalities emanated by U\&C. The local governments elected by U\&C seem to effectively show target fiscal functions different from the municipalities ruled by parties. This result is consistent with what was reported by Wittman (1995), who observes that municipalities with higher political competition should show higher levels of tax collection of their own.

In addition, in this study we find that shocks from the contributions inhibit significantly the dynamics of the participations for prolonged periods of time, of no less than six years, and more intensely in municipalities ruled by U\&C. In addition, shocks from the participations increase the tax collection by municipalities in the short term (particularly those ruled by $\mathrm{U} \& \mathrm{C}$ ), at the same time they stimulate higher amounts of contributions, in the short and long term, in the two groups of municipalities; these results agree with those found in Cárdenas and 
municipios con mayor competencia política deberían registrar mayores niveles de recaudación propia.

En adición, en este estudio encontramos que choques provenientes de las aportaciones inhiben significativamente la dinámica de las participaciones por periodos de tiempo prolongados, no menores a seis ańos y de manera más intensa en municipios regidos por UyC, Además de que los choques de participaciones incrementan la recaudación propia de los municipios en el corto plazo (en particular los regidos por $\mathrm{UyC}$ ), al mismo tiempo impulsan mayores montos de aportaciones, en el corto y largo plazo, en los dos grupos de municipios; resultados que concuerdan con los encontrados en (Cárdenas y Sharma, 2011; Benton, 1992; Guadarrama, 2006; Moreno, 2003; Unda y Moreno 2015).

La hipótesis de integración política de Sato (2006) e Inman and Rubinfeld (1997) sugiere que el gobierno central pueden mantener unidas a las regiones en descontento empleando a las transferencias federales como instrumento de adhesión. En este estudio encontramos evidencia de que municipios en descontento político han recibido montos de transferencias per cápita mayores y que las transferencias federales inhiben el esfuerzo recaudatorio de los municipios. Como tal, los resultados parecen confirmar la noción de que las transferencias se utilizan como mecanismos para asegurar la estabilidad y cooperación, más que para incentivar la capacidad fiscal local (Inman y Rubinfeld, 1997) o son empleadas como gasto de inversión para mantener la unidad política de las regiones (LeiteMonteiro y Sato, 2003), en este caso de los municipios regidos por $\mathrm{UyC}$ en el Estado de Oaxaca.

\section{NOTAS}

${ }^{1}$ En este estudio consideramos al esfuerzo fiscal como una variable proxy de la autonomía de los municipios en México. In this study we consider the fiscal effort as a proxy variable of the autonomy of the municipalities in Mexico.

${ }^{2}$ Por ejemplo, si la filiación política del presidente municipal es del PRI se observa una mayor dependencia de las participaciones, que la que se observa si la filiación del presidente municipal es del PAN, en tanto que la afiliación política al PRD no es estadísticamente significativa. For example, if the political affiliation of the municipal president is with PRI, a greater dependency on participations is observed,
Sharma (2011), Benton (1992), Guadarrama (2006), Moreno (2003), and Unda and Moreno (2015).

The hypothesis of political integration by Sato (2006) and Inman and Rubinfeld (1997) suggests that the central government can keep regions in discontentment united by using federal transferences as an adhesion instrument. In this study we find evidence that municipalities with political discontentment have received higher amounts of per capita transferences and that federal transferences inhibit the tax collection effort of the municipalities. As such, the results seem to confirm the notion that transferences are used as mechanisms to ensure stability and cooperation, rather than to stimulate the local fiscal capacity (Inman and Rubinfeld, 1997), or they are used as investment spending to maintain the political unity of the regions (Leite-Monteiro and Sato, 2003), in this case of the municipalities ruled by $\mathrm{U} \& \mathrm{C}$ in the state of Oaxaca.

- End of the English version-

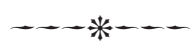

than that which is seen if the affiliation of the municipal president is with PAN, while the political affiliation to PRD is not statistically significant.

${ }^{3}$ Este sistema electoral contiene mecanismos de votación específicos y se basa en una serie de principios que emanan de la naturaleza propia del sistema de cargos. El derecho consuetudinario en el que se basa este sistema tiene dos características: la práctica reiterada a través del tiempo y la opinión de que es obligatorio. Además de Oaxaca, está reconocido constitucionalmente este sistema en los estados de Tlaxcala y Chiapas (Ramírez, 2006). * This electoral system contains specific voting mechanisms and is based on a series of principles that emanate from the nature of the charges system. The customary law on which this system is based has two characteristics: reiterated practice throughout time and the opinion that it is mandatory. In addition to Oaxaca, this system is recognized constitutionally in the states of Tlaxcala and Chiapas (Ramírez, 2006).

${ }^{4}$ Algunos autores han señalado en efecto que el monto de las transferencias federales a municipios de esta región y en particular a Chiapas se han incrementado considerablemente desde entonces (López y Mayo, 2015). Some authors have pointed out, in effect, 
that the amount of the federal transferences to the municipalities of this region and in particular to Chiapas has increased considerably since then (López and Mayo, 2015).

${ }^{5} \mathrm{~A}$ diferencia de la primera diferencia o desviación simple respecto a la media, el procedimiento de Helmert consiste en obtener las desviaciones respecto a la media de las observaciones futuras en cada variable, lo que garantiza que los valores rezagados de las variables explicativas continúen siendo instrumentos válidos. Este método asegura que las variables explicativas en todo el tiempo $t$ sean ortogonales con los errores y se cumpla con la independencia de los residuos y los residuos al cuadrado (homoscedasticidad). * In contrast with the first difference or simple deviation with regards to the mean, the Helmert procedure consists in obtaining the deviations with regards to the mean of the future observations in each variable, which guarantees that the lagged values of the explicative variables continue being valid instruments. This method ensures that the explicative variables during the whole time $t$ are orthogonal with the errors and that the independence of the residues and the square residues (homoscedasticity) is achieved. 'Para mayores detalles sobre la teoría de VAR con datos panel, así como problemas de identificación, estimación, inferencia y el uso de los rezagos de $z_{i, t}$ como variables instrumentales el lector puede consultar las contribuciones seminales de Holtz-Eakin et al. (1988). * For more details about the ARV theory with panel data, as well as about problems of identification, estimation, inference and the use of the $z_{i, t}$ lags as instrumental variables, the reader can consult the seminal contributions by Holtz-Eakin et al. (1988).

${ }^{7}$ Estimación de VAR con datos panel basada en el programa de Stata desarrollado por Love y Ziccino (2006). ARV estimation with panel data based on the Stata software developed by Love and Ziccino (2006).

${ }^{8} \mathrm{El}$ orden del VAR se determinó con criterios de decisión de Schwartz y Bayes. The order of the ARV was determined with decision criteria from Schwartz and Bayes.

${ }^{9} \mathrm{Se}$ aseguró la estacionariedad de cada variable empleando el procedimiento de Helmert de Arellano y Bolver. La estacionariedad de las variables fue verificada adicionalmente con el procedimiento de LevinLin-Chu para raíces unitarias en datos panel. The stationarity of each variable was ensured using the procedure by Helmert de Arellano and Bolver. The stationarity of the variables was additionally verified with the procedure by Levin-Lin-Chu for unitary roots in panel data.

${ }^{10} \mathrm{La}$ respuesta de los ingresos propios a choques de participaciones en municipios elegidos por partidos es positiva y significativa solo con niveles de confianza del $90 \%$. The response from own income to shocks from participations in municipalities chosen by parties is positive and significant only with levels of trust of $90 \%$.

${ }^{11}$ Nuestras estimaciones no muestran un impacto significativo de la autonomía a las transferencias federales. Our estimations do not show a significant impact of the autonomy on federal transferences.

${ }^{12} \mathrm{La}$ causalidad solo va de las transferencias al esfuerzo recaudatorio de los municipios. La respuesta de las participaciones y de las aportaciones a choques provenientes de la recaudación propia no es estadísticamente significativa. The causality only goes from transferences to the tax collection effort of the municipalities. The response from the participations and the contributions to shocks from their own tax collection is not statistically significant.

${ }^{13}$ Díaz Cayeros (2004) e Ibarra et al. (1999) han encontrado un impacto positivo, significativo y persistente de las participaciones sobre la recaudación propia de los municipios en México. Consistente con nuestro resultado, Sour $(2004,2008)$ reporta que las aportaciones del Ramo 33 desincentivan la recaudación municipal propia. Díaz Cayeros (2004) and Ibarra et al. (1999) have found a positive, significant and persistent impact of the participations on the tax collection by municipalities in Mexico. Consistent with our findings, Sour $(2004,2008)$ reports that the contributions from Branch 33 discourage municipal tax collection.

\section{LITERATURA CITADA}

Alesina, A., and E. Spolaore. (1997). "On the Number and Size of Nations". Quarterly Journal of Economics 112 (4): $1027-$ 56.

Arellano, M., y O. Bover (1995). "Another look at the instrumental variable estimation of error component models". Journal of Econometrics, 68, 29-51.

Becker, G. S. (1983). A Theory of Competition Among Pressure Groups for Political Influence. The Quarterly Journal of Economics, 371-400.

Bello, R. y J. Espitia (2011). "Distribución regional de las transferencias intergubernamentales en Colombia 1994-2009”, 
Documentos y Aportes en Administración Pública y Gestión Estatal, vol. 11, núm. 16, pp. 7-50, Argentina.

Benton, J. E. (1992). "The Effect of Changes in Federal Aid on State and Local Government Spending”. Publius, 22:71-82.

Bell, M. E. \& Bowman J. H. (1987), «The Effect of Various Intergovernmental Aid Types on Local Own-Source Revenues: The Case of Property Taxes in Minnesota.» Public Finance Quarterly 15: 282-297.

Boadway, R., \& Hobson, P. (1993). Intergovernmental Fiscal Relations in Canada (No. 96). Canadian Tax Foundation, Toronto.

Boadway, R. (2002). "The Role of Public Choice Considerations in Normative Public Economics.” In Political Economy and Public Finance: The Role of Political Economy in the Theory and Practice of Public Economics, ed. S. L. Winer and H. Shibata, 47-68. Cheltenham, United Kingdom: Edward Elgar.

Bolton, P., \& Roland, G. (1997). The Breakup of Nations: a Political Economy Analysis. The Quarterly Journal of Economics, 1057-1090.

Brock, R., \& Owings, S. (2003). The Political Economy of Intergovernmental Grants. Regional Science and Urban Economics, 33(2), 139-156.

Cabrera, Fernando y René Lozano (2011). Relaciones Intergubernamentales y el Sistema de Transferencias en México: Una Propuesta de Nivelación Interjurisdiccional, Universidad de Quintana Roo y Miguel Ángel Porrúa, México.

Cárdenas, O. J. y Sharma A. (2011). "Mexican Municipalities and the Flypaper Effect", Public Budgeting and Finance, 31(3), Wiley-Blackwell, EUA, pp. 73-93.

Díaz Cayeros, Alberto (2004). "El federalismo y los límites políticos de la redistribución”, Gestión y Política Pública, 13(3), segundo semestre, Centro de Investigaciones y Docencia Económicas, México, pp. 663-687.

Dixit, A., Grossman, G. M., \& Helpman, E. (1997). Common Agency and Coordination: General Theory and Application to Government Policy Making. Journal of political economy, 105(4), 752-769.

Dixit, A., \& Londregan, J. (1996). The Determinants of Success of Special Interests in Redistributive Politics. Journal of politics, 58, 1132-1155.

Dixit, A., \& Londregan, J. (1998). "Fiscal Federalism and Redistributive Politics.” Journal of Public Economics 68 (2): 153-80.

Grossman, P.J. (1994). "A Political Theory of Intergovernmental Grants”, Public Choice, 78:295-304.

Guadarrama, C. V. (2006). Determinantes del gasto estatal en México. Gestión y Política Pública, 15(1), 83-109.

Hernández, Fausto y Jarillo, Brenda (2007). “Transferencias condicionadas federales en países en desarrollo: el caso del FISM en México", Estudios Económicos, vol. 22, núm. 2, juliodiciembre, pp. 143-184.

Holtz-Eakin, D., Newey, W. y Rosen, H. (1988), "Estimating Vector Autoregression with Panel Data". Econometrica, 56, $1371-1395$.

Ibarra, Jorge, Alfredo Sandoval y Lida Sotres (1999). Participaciones Federales y Dependencia de los gobiernos municipales en México, 1975-1995", Serie de Documentos de Trabajo del Departamento de Economía, ITESM.

Ibarra, Jorge y Lida Sotres (2009). "Determinantes de la recau- dación del impuesto predial en Tamaulipas: Instituciones y zona frontera norte" en Frontera Norte, Vol. 21, Núm. 42, Julio-Diciembre.

Ibarra, Jorge y Héctor González (2009). "Aspectos políticos de la dependencia financiera en los municipios mexicanos”, Serie de Documentos de Trabajo del Departamento de Economía, ITESM.

Ibarra, Jorge (2011). "Entorno político y dependencia financiera de los estados mexicanos", Gestión y Política Pública, Volumen XXII, Número 1, 1er. semestre de 2013, pp. 3-44.

Inman, R. P., \& Rubinfeld, D. L. (1996). Designing Tax Policy in Federalist Economies: an Overview. Journal of Public Economics, 60(3), 307-334.

Inman, R. P., \& Rubinfeld, D. L. (1997). "Rethinking Federalism.” Journal of Economic Perspectives 11 (4): 43-64.

Isusquiza, E. (2014). "Desigualdad, crecimiento económico y descentralización fiscal: Un análisis empírico para México", Premio Nacional de Finanzas Públicas, Centro de Estudios de las Finanzas Públicas. http://www.cefp.gob.mx/portal_archivos/convocatoria/pnfp2014/mencionhonorificapnfp2014.pdf

Johansson, E. 2003. "Intergovernmental Grants as a Tactical Instrument: Empirical Evidence from Swedish Municipalities”. Journal of Public Economics 87 (5-6): 883-915.

Labastida, J., N. Gutiérrez y J. Flores (2009), Gobernabilidad en Oaxaca. Municipios de competencia partidaria y de usos y costumbres, México, IIS-UNAM

Leite-Monteiro, M., \& Sato, M. (2003). Economic Integration and Fiscal Devolution. Journal of Public Economics, 87(11), 2507-2525.

López, J., \& Mayo, B. (2015). Federalismo fiscal. Chiapas y Nuevo León: un análisis comparativo. Economía UNAM, 12(34), 106-123.

Love, I. y Zicchino, L. (2006), "Financial Development and Dynamic Investment behavior: Evidence from panel VAR". The Quarterly Review of Economics and Finance. 46 (2), 190-210.

Mendoza, P. B. (2009). "Participación social armada en Oaxaca. Ejército Popular Revolucionario", Estudios Políticos, vol. 9, mayo-agosto 2009, pp. 61-83.

Moreno, C. L. (2003). Fiscal Performance of Local Governments in Mexico: The Role of Federal Transfers, México, CIDEDAP.

Owalabi, Kunle. (2004). “'La legalización de los usos y costumbres ha contribuido a la permanencia del gobierno priista en Oaxaca? Análisis de las elecciones para diputados y gobernadores, de1992 a 2001," Foro Internacional, 177, XLIV, 2004 (3), 474-508.

Peña, J. y L. A. Wence (2011). La distribución de transferencias federales para municipios, ¿qué incentivos se desprenden para el fortalecimiento de sus haciendas públicas? INDETEC, revista trimestral No. 115, Oct.-Dic.

Porto, A., \& Sanguinetti, P. (2001). Political Determinants of Intergovernmental Grants: Evidence from Argentina. Economics \& Politics, 13(3), 237-256.

Ramírez, P. A. (2006). Elecciones por usos y costumbres en México. Revista Letras Jurídicas, 14.

Ruíz-Porras, Antonio y Nancy García-Vázquez, N. (2013), “La reforma hacendaria y las transferencias en los municipios de Jalisco 2005-2011" en Economía Informa, México: UNAM, 
núm. 381, julio - agosto 2013, publicación bimestral, pp. 29-40.

Ruiz Porras, Antonio y Nancy García- Vázquez (2014), "El Federalismo fiscal y las transferencias planeadas hacia los municipios mexicano: criterios económicos y políticos”, en Espiral, Estudios sobre Estado y Sociedad, Vol. XX, No. 59, Enero/ Abril, pp. 69- 86.

Sánchez Almanza, A. (2000). "Marginación e ingreso en los municipios de México, análisis para la asignación de recursos fiscales”, Colección Jesús Silva Herzog, Grupo editorial Miguel Ángel Porrúa.

Sato, M. (2007). "The Political Economy of Interregional Grants", en Public Sector Governance and Accountability Series. Intergovernmental Fiscal Transfers: Principles and Practices, Boadway, R. y Shah, A. (Editores), The World Bank, Washington. 173-197.

Secretaría de Finanzas (2011). Datos de la recaudación del impuesto predial de los municipios del Estado de Oaxaca y de las participaciones y aportaciones asignadas a los municipios del Estado de Oaxaca.

Sobel, R. S. \& Crowley, G. R. (2014). "Do Intergovernmental Grants Creat Ratches in State and Local Taxes?" Public Choice, 158:167-187.

Sour, Laura (2004). "El sistema de transferencias federales en México: ¿Premio o castigo para el esfuerzo fiscal de los gobiernos locales urbanos?", Gestión y Política Pública, 13(3),
Centro de Investigaciones y Docencia Económicas, México, pp. 733-751.

Sour, Laura (2008). "Un repaso sobre los conceptos de sobre capacidad y esfuerzo fiscal, y su aplicación en los gobiernos locales mexicanos", Estudios Demográficos y Urbanos, 23(2), El Colegio de México, México, pp. 271-297.

Stine, W. F. (1994). "Is Local Government Revenue Response to Federal Aid Symmetrical? Evidence From Pennsylvania County Governments in an Era of Retrenchment." National Tax Journal XLVII: 799-816.

Unda, M. y Moreno, C. (2015). "La recaudación del impuesto predial en México: un análisis de sus determinantes económicos en el período 1969-2010", Revista Mexicana de Ciencias Politicas y Sociales, Universidad Nacional Autónoma de México, Nueva Época, Año LX, núm. 225, sept.-dic., pp. 45-78.

Unikel, L. (1976). El desarrollo urbano en México, El Colegio de México.

Wittman, D. A. (1995). The Myth of Democratic Failure: Why Political Institutions are Efficient. University of Chicago Press.

Zhuravskaya, E. V. (2000). Incentives to Provide Local Public Goods: Fiscal Federalism Russian Style. Journal of Public Economics, 76(3), 337-368. 